\title{
The cistern-system of early modern Venice: technology, politics and culture in a hydraulic society
}

\section{David Gentilcore ${ }^{1}$ (D)}

Received: 8 February 2021 / Accepted: 21 September 2021 / Published online: 5 October 2021

(C) The Author(s) 2021

\begin{abstract}
At a time when European cities depended on three sources of fresh water for their domestic and industrial needs - rivers, spring-fed aqueducts and groundwater wells - early modern Venice added a fourth possibility: a dense network of cisterns for capturing, filtering and storing rainwater. Venice was not unique in relying on rainwater cisterns; but nowhere in Italy (indeed in Europe) was the approach so systematic and widespread, the city concerned so populous, the technology so sophisticated and the management so carefully regulated as in the lagoon city. To explore Venice's cistern-system, a range of primary sources (medical treatises, travellers' accounts, archival records) and the contributions of architectural, medical and social historians, and archaeologists are analysed. The article examines the system's functioning and management, including the role of the city's acquaroli or watermen; the maintenance of freshwater quality throughout the city, in the context of broader sanitation measures; and the place of the "wells" and fresh water in daily life in Venice. As a means of teasing out the myriad links between nature, technology and society in early modern Italy, the article concludes with a brief comparison of the politics of water supply management in the very different urban realities of (republican) Venice, (viceregal) Naples and (papal) Rome.
\end{abstract}

Keywords cistern-system - Venice; fresh water supply management · Venice; early modern - Venice; water, disease and health; hydraulic society; rainwater cisterns

\section{Introduction}

In the sixteenth century Venice was one of Europe's liveliest and most cosmopolitan cities, but in 1575-77 it suffered its worst plague epidemic, which is estimated to have killed more than a quarter of the city's population, numbering some 180,000 on the eve of the epidemic (Preto 1978, p. 112). With plague still raging, city authorities and medical doctors sought

David Gentilcore

david.gentilcore@unive.it

Dipartimento di Studi Umanistici, Università Ca' Foscari Venezia, Venice, Italy 
to identify its causes. In line with the medical thinking of the time, this was put down to a range of environmental factors, such as the accumulation of filth which resulted in the "corruption of the air and water" and the build-up of disease-causing "miasmas" (Palmer 1978, pp. 238-279; Sansa 2002; Wheeler 2007; Cohn 2010, pp. 124-128; Henderson 2010). In response, the city's health officials, the Provveditori alla Sanità, took a variety of measures in Venice itself and in the surrounding Terraferma: prohibiting rice cultivation and the retting of hemp (which required standing water), draining swamps, cleaning latrines, burning corpses and possessions, limewashing houses and isolating plague sufferers. The authorities also considered a myriad of remedies and solutions proposed to them by various parties. This included a plan for a "deep clean" of the city's canals, streets and wells, put before the Savi ed esecutori alle acque, a board responsible for water management throughout the lagoon, in December 1576. ${ }^{1}$ But one man posited an even more focused explanation and solution. Annibale Raimondo, a Veronese astrologer and (perhaps) doctor, long-time resident in Venice, blamed the city's drinking water for the epidemic (Raimondo 1576).

Raimondo recounts that on the night of 11 October 1574 an extraordinarily high tide overwhelmed Venice, washing over the canals and streets and flooding all of the city's wells with a mixture of sea water and filth. This was accompanied by prolonged heavy rains which had begun a few days earlier, resulting in a mixture of salt and fresh water in the city's wells, the only supply of domestic fresh water. Raimondo was convinced that over time this mixing would generate "some harmful and dangerous effect" in those who drank it, so the following March he went before the Provveditori alla Sanità to warn the officials that if the wells were not fully drained by the autumn "there would be horrible infirmities, pestilential and deadly, in the city of Venice" (Raimondo 1576, unpaginated). The health officers followed Raimondo's advice and had the wells cleaned, removing "a certain muddy mixture so foul that it caused illness". However they were unable to remove all of the salt water, which had accumulated in the sand around the wells and which slowly and constantly filtered back into them. Most affected were the city's poor who, "unable to afford wine" had no choice but to quench their thirst with this "mixed" well water and to cook their vegetables in it, such that it penetrated "through all parts of the body". Those who consumed it slowly became prey to "those infirmities that are of a malign nature, such as petechial fevers", women more than men because of their "weaker complexions" (Raimondo 1576, unpaginated). All of the city's six districts (sestieri), all of its parishes (contrade), all of its houses were affected to some extent. By May of 1576 the poor had been consuming this water for some 15 or 16 months but the resulting petechial fevers were ignored by doctors, allowing the diseases to worsen and turn into plague. ${ }^{2}$ Thus for Raimondo, as long as the fresh water in the wells predominated over the salt water, then the resulting seasonal diseases were still curable; but the more the salt water filtered down into the wells the more the resulting diseases "came to resemble pestilence". At this stage the disease had become so fierce that it was "easily able to pass from hand to hand, body to body". The result was a fully-fledged plague epidemic.

In addition to Raimondo's short treatise on the subject, his singular explanation was picked up by the notary Rocco Benedetti in his account of the plague in Venice, who also echoed Raimondo's criticisms of the elite doctors for their failure to act and treat patients

\footnotetext{
${ }^{1}$ Archivio di Stato, Venice (hereafter ASVe), Savi ed esecutori alle acque, reg. 270, fols. 11-13 (Preto 1984, p. 97).

${ }^{2}$ At a time when medicine did not identify "plague" as a specific disease entity but as a spectrum of diseases, it was not uncommon for diseases to shift in their nature and hence their deadliness.
} 
(Benedetti 1577, unpaginated). And twenty years later the memory of the flood event and the resulting plague were still alive, and convincingly linked, in many of the city's surviving inhabitants, among them the lawyer Filippo Zorzi.

But who doubts [Zorzi rhetorically asked] whether the plague which afflicted the city of Venice in the years 1575 and 1576 originated from other cause than that of the flood of sea water which, with furious and overwhelming flow, invaded all the streets and ground-floor dwellings, filling the city with excessive damp and spoiling the waters of almost all of its wells, bringing with it that terrible and pestilential contagion? (Zorzi 1596, p. 8).

In order to understand why Raimondo's unusual explanation remained so convincing we need to make sense of the lagoon city's unique freshwater supply, how it was managed in the context of oversight of the lagoon environment more broadly, and what its significance was for those who lived in and visited the city. To do this we shall consider a range of primary sources (medical treatises, travellers' accounts, archival records) and the contributions of architectural, medical and social historians, and archaeologists.

Venice can be said to exemplify a "hydraulic society" - if we take this to mean one in which there existed fundamental interdependencies between water management, infrastructure systems and socio-political organisation (Price 1994). Karl Wittfogel's pioneering "hydraulic hypothesis" (1957) may have been more or less abandoned as an explanatory model but the issues it raised are still valid and thought-provoking (Bichsel 2016, p. 369). Shorn of its technological determinism and its focus on particular forms of autocratic rule, and especially when we consider recent critical re-interpretations, Wittfogel helps us think about the "myriad relations between society, nature and technology" (Obertreis et al. 2016, p. 172). When it comes to exploring these myriad relations with reference to Venice, I prefer "hydraulic society" to the more generic "amphibious" (Ciriacono 2006, pp. 157-193; Vanzan Marchini 2009), although the proximity to water is obviously central to both labels. That said, rather than take large-scale water management (i.e. hydraulics, irrigation and land reclamation) as our focus, as it was for Wittfogel, and which in any case has already been the subject of expert study for Venice and the Veneto (Ciriacono 2006, pp. 62-100 and 101156; Ciriacono 2018), we shall shift our gaze to the supply of fresh water for domestic uses. How did Venice - this unique, man-made "ecological improbability" (Martin and Romano 2000, pp. 1-2) - provide itself with fresh water? Moreover, if water is "a medium through which social and political relations are negotiated" (Tilt 2015, p. 5), what can Venice's use and management of freshwater resources tell us about the nature of power and society in the early modern city? This will be attempted, by way of conclusion, through a short comparison with the cities of Naples and Rome.

\section{The cistern-system of Venice}

In his description of Venice and its political-administrative system, written towards the end of the fifteenth century, the diarist Marin Sanudo remarked:

Nothing originates here in this city and yet anything whatsoever can be had, in abundance. Everything abounds except fresh water, at any time, such that Venice is in water and yet has no water. There are wells in all of the parish squares and houses, 
but in times of drought they get all used up. And so it is that barges full of water taken five miles away at Lizzafusina, on the Terraferma, from the river Brenta, is sold and the well galleries filled from the barges, to the cry of "Water now" [Acqua mo], and it is sold at eight pails a soldo. Truthfully, it is laughable to be in water and yet have to buy it (Sanudo 1980, pp. 37-38).

The irony did not stop there. In addition to the city which emerged out of salt water having periodically to bring in supplies of fresh water, is the further irony that freshwater wells came to occupy much of the underground space that was not taken up by the city's dense network of saltwater canals. As a result, a significant (and ever increasing) part of the city's built environment actually lay over fresh water. In fact, what were almost universally referred to as "wells" were not wells at all but underground cisterns; that is, rather than tapping into groundwater-which would have been brackish in any case - the city's "wells" were actually complex devices for capturing, filtering and storing rainwater. At a time when European cities depended on three sources of fresh water for their domestic and industrial needs — rivers, spring-fed aqueducts and groundwater wells (Roche 1984, p. 385)—Venice thus added a fourth possibility. The city was not unique in early modern Italy in relying on rainwater capture. Indeed, in early medieval Italy cisterns may have been more common than wells, though these were mostly private and domestic (Squatriti 1998, pp. 23-32). Into the early modern period, communities in southern Italy, such as port town of Bari and the cliff-side dwellings of Matera, not to mention the small Sicilian island of Pantelleria, relied on cisterns (Veneziani 2016; Laureano 1993; Grano 2020; Mantellini 2015; Dell'Aquila et al. 2020). But nowhere in Italy (indeed in Europe) was the approach so systematic and widespread, the city concerned so populous, the technology so sophisticated and the management so carefully regulated as in Venice. ${ }^{3}$

At the end of the eighteenth century Giacomo Filiasi recounted how the early Venetians had made a virtue of necessity in developing a method of "making water from the clouds supremely healthy and perfect" - a method that was always a source of surprise to foreign visitors (Filiasi 1796-97, vol 6, pt 2: 149). And indeed on his very first sight of Venice, in June 1645, the ever-curious John Evelyn remarked on how the city was "one of the most miraculously plac'd of any of the whole world, built on so many hundred islands", and that "it has neither fresh nor any other but salt water, save what is reserved in cisterns of the raine and such as is daily brought them from Terra firma in boates" (de Beer 1959, p. 220). The city's "cistern-system" consisted of the two key elements identified by Evelyn: (i) the "Venetian-style well" (pozzo alla veneziana), of which there would eventually be more than 5,000 in the city; and (ii) the use of barges (burchi) to top these up periodically with river water brought in from the mainland. ${ }^{4}$ This cistern-system represented the exclusive source of fresh water for the city's population for both domestic and industrial uses. It was arguably every bit as complex to maintain and manage as any of the "monumental" infrastructures that characterised other Italian cities, such as the ancient aqueduct-fed underground system of Naples (Gentilcore 2019) or the renewed aqueduct-fed fountains of Rome (Rinne 2010;

\footnotetext{
${ }^{3}$ Amsterdam, like other towns in the Netherlands, made use of rainwater cisterns to supplement other sources of fresh water, like the canals. Thus in 1505, with the quality of fresh water from the canals deteriorating due to domestic and industrial pollution, Amsterdam's city council built nine rainwater cisterns (Loen 2020, p. 90).

${ }^{4}$ Occasional attempts were made to drill artesian wells into the bedrock underneath the city but without success until 1846 (Giormani 2010, p. 347).
} 
Long 2018, pp. 63-91), to the extent that the Venetians brought their acquired expertise to their overseas dominions, like Crete (Tsakiri 2018).

The "Venetian-style well" or well-filtered cistern was a complex structure (Filiasi 1796, vol. 6 pt 2: 151-152; Lucchesi 1805, pp. 20-22; Costantini 1984, pp. 14-15; Giormani 2010, pp. 326-327; Bortoletto 2011). ${ }^{5}$ In terms of its primary function, it had in common with cisterns elsewhere in the Mediterranean that it was a statically situated, lined container, designed to receive rainwater from an external source such as an adjacent roof-top, channelled into it (Mays et al. 2013; Klingborg and Finné 2018, p. 115). But here the similarity ends. The emerging lagoon city adapted pre-existing cistern design and technology, inherited from the ancient world and revived in the Middle Ages (Magnusson 2001, pp. 1-35; Sowina 2016, pp. 139-156), to its own very specific requirements, constraints and material availabilities. Thus, the Venetian-style "well" was typically located in the middle of a public square or private courtyard, on the surface of which only the marble or brick well-head (vera, literally "ring" or "hoop" in Venetian) would be visible, providing support for those drawing water as well as a decorative element. Surrounding the well-head was the broad stone-paved area of the square, sloping down slightly on all sides from the well-head and interspersed with gully grates made of Istrian stone (pilelle) which were pierced with holes (gattoli) through which the surface water would drain. It would then collect in underground galleries or tanks made of brick (cassoni). The actual cistern occupied most of the vast area underneath the square. This consisted of a large broad basin, round or four-sided, dug to a depth of 3-4 m below the normal high-tide level. This was filled with sand, brought in from the Lido, known as the spongia (literally "sponge"). From the galleries, the water would

\footnotetext{
${ }^{5}$ In the past tense here, since the entire system of cisterns was eventually de-commissioned in the $1930 \mathrm{~s}$, following construction of the aqueduct by the Compagnie Générale des Eaux bringing fresh water from the mainland in 1884 (Franck 1999, pp. 219-242; Giormani 2010, pp. 361-363), and are now strictly ornamental. The cistern-system continued to impress throughout the nineteenth century, the French scientist and author Louis Figuier referring to it as proof of the saying that "necessity is the mother of invention" in his survey of "the marvels of industry" (Figuier 1875, vol. 3 pp. 118-121). I will refer to them as cisterns throughout, even if the sources almost always call them "wells", as do Venetians to this day.
}

Fig. 1 The Venetian-style well or well-filtered cistern. Author's adaptation of a period photograph of the Campo della Maddalena, Venice (Ongania 1911, no. 162). The whole square has been raised up to discourage salt-water infiltration; the well-head dates from the early sixteenth century

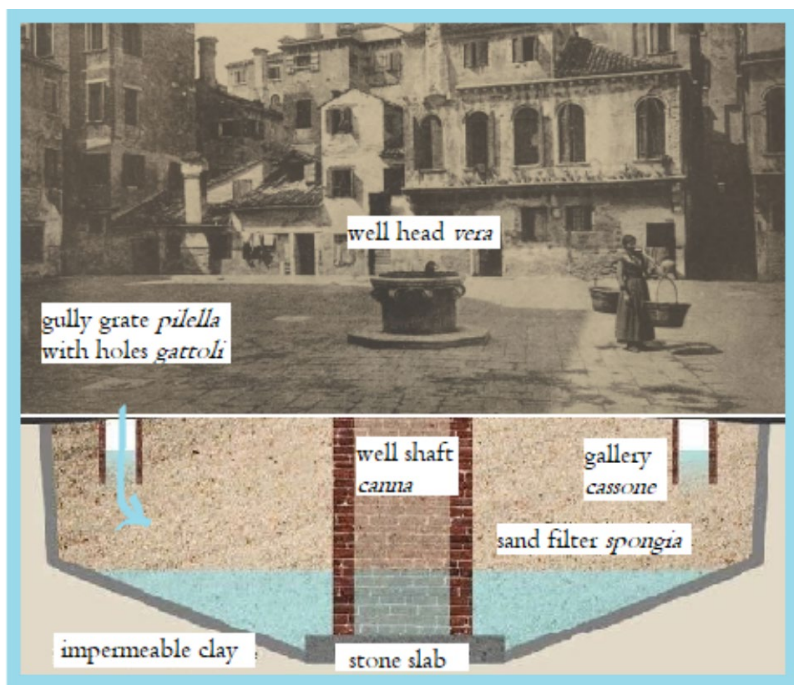


then filter through the sand, as if in imitation of a natural water table. The cistern's walls and floor were lined with a layer of impermeable clay half a metre thick to prevent the rainwater from flowing away (and saltwater from flowing in). Located in the centre of the cistern was the well-shaft (canna), built of special bricks (pozzoli) and water-permeable mortar (two parts clay to one part sand), into which the water would accumulate. The well-head sat on top of the shaft, allowing access to the water below.

From as early as the eleventh and twelfth centuries rainwater capture was a major concern in the emerging city, enshrined in law, part and parcel of the city's unique struggle with its watery environment (Crouzet-Pavan 1992, 1: 220-221, 232-234). In 1322 Venice's sovereign assembly, the Maggior Consiglio, decreed the construction of fifty new public cisterns, followed again in 1424 by the building of thirty additional cisterns in various locations around the city (Marangoni 1974, p. 54). Occasionally, private individuals added to this number by providing for the construction of a public cistern. Thus, in May 1348, during the first deadly plague epidemic, and on his deathbed due to it, the merchant Marco Arian left 300 gold ducats for the construction of two "wells", to be "common to the people and good men of this parish", in Campo dell'Angelo Raffaele. ${ }^{6}$ By July of the following year one of the cisterns was completed, decorated with his arms, where it remains to this day (Calabi and Galeazzo 2015, pp. 257; Tüskés 2010, p. 53). High in Arian's mind was the need for supplies of safe, fresh water especially during times of plague - a link to Raimondo over two centuries later.

When it comes to the smaller-scale domestic cistern of the Mediterranean, it is likely that the decision to build one influenced how the adjacent building was constructed and where it was situated (Mantellini 2015, p. 412; Klingborg and Finné 2018, p. 128). In Venice, this was taken to an entirely new level: an example where the built environment was as much adapted to the need for fresh water as the other way around. By the sixteenth century much of Venice's open space - its squares and streets - was dedicated to water capture in order to supply these cisterns. As noticed by the visiting Michel de Montaigne in 1580, they are all paved "on the slope, so there is never any mud" (Montaigne 1903), though he missed their real purpose. As the city's population increased, new cisterns were built to meet the demand, both public and private. The Renaissance humanist and scholar Francesco Sansovino counted 147 "wells" in the city, each square having one (Sansovino 1581, p. 140v.). Writing in 1617, based on travels taken in the early $1590 \mathrm{~s}$, the English visitor Fynes Moryson reported that Venice had "one hundred and fifty wells for the common use of the citizens" (Moryson 1907, I: 426). This declined slightly to 147 in 1768, when only 105 of these were judged "good" or "acceptable, but more good than bad", the rest were either "acceptable, but more bad than good" or "bad" (Costantini 1984, p. 94). Improvements were made in the following decades, such that by 1795 there were 157 public cisterns (ibid., p. 95) and 160 by the beginning of the nineteenth century, in addition to some 140 "semi-public" cisterns, located in courtyards (Lucchesi 1805, pp. 33). Finally, there were several thousand private cisterns, because "all of the grandest houses, palaces and convents have one or more wells, corresponding [in size] to the overall land area they occupy" (Lucchesi 1805, pp. 33). To this list we should also add tradesmen such as dyers who needed water for their activities - a sixteenth-century dye-house located on the Grand Canal, excavated in 2008, had a cistern of the capacity of some 36,000 L (Bortoletto 2008, 244-246) - even if their water did not

${ }^{6}$ ASVe, Notarile, Testamenti, b. 1195, no. 75, “Testamento di Marco quondam Antonio Arian”, 28 May 1348 (Calabi and Galeazzo 2015, pp. 257-258). 
necessarily need to be of drinking quality. In fact, although private cisterns numbered 5,000, only 2,000 were judged to produce water suitable for drinking (Lucchesi 1805, pp. 33). And they varied greatly in size. If the cistern of the Dominican monastery of Santi Giovanni e Paolo had a rainwater capture surface of 2,500 square metres, many private cisterns barely reached a hundred (Guerzoni and Tagliapietra 2006, p. 190).

Material and archival evidence shows that until the end of the fifteenth century these cisterns required large open spaces and were always located outdoors, in public squares (for the poor) or courtyards (for the better off). However, by Sansovino's time there had been a further, significant development. In Venetian buildings "stone gutters wind all around the roof, along which the rainwater flows and down through hidden drainpipes into the wells, where it is filtered of the larger particles, returning it to the people's benefit, there being no rivers or groundwater in which fresh water might can be found" (Sansovino 1581, p. 140v.). During the course of the sixteenth century, in response to constant population growth, a new building style had been developed to house more people, which incorporated indoor cisterns lying underneath the buildings to meet the resulting demand for more fresh water. The solution was what the architectural historian Giorgio Gianighian has called the Venetian "complex" or "double house" (Gianighian 1982, 2004). In this building type - adaptable, profitable and making the most of available space - each unit in a block of dwellings shared an internal courtyard but had its own outer door, interior stairway and indoor underground cistern, fed by rainwater from the roof and the limited paving around the building. These buildings were intended primarily for rent and became a very common housing type throughout the city, used in almost every residential complex that was not a palace. An example is the four-unit Castelforte complex, built in 1550, each with its own cistern. Because the cistern was placed astride a load-bearing wall, it was possible to draw water from two neighbouring rooms, the entrance hall and the laundry. Each of the four cisterns was over $3.5 \mathrm{~m}$ deep, with its own well-shaft, providing an estimated $138 \mathrm{~L}$ of water per day if full (Gianighian 2005, p. 54).

A similar solution was employed in multiple-occupant dwellings, where the well-head would be divided in two by a wall, for access by two adjacent units (so that each would have a semi-circular well-head). This is the case of a humbler building type which consisted of a single block of several units located around a small courtyard: exemplified by the structure at Cannaregio $3777^{7}$ excavated by archaeologists in 2010 (Bortoletto 2011, 197-201). Today it consists of three units, over three floors, for a total of 133 square metres. As the dig revealed, the units shared a single cistern. Its three galleries (cassoni) were located at different points under the structure, with a capacity of three cubic metres each and fed by earthenware pipes from the roof. Rainwater from the galleries was ultimately deposited in the single round well-shaft, constructed of two layers of radial brickwork. The brick well-head was divided in two by a wall of the building, with one half accessible from the courtyard and the other from inside the structure. The cistern provided an estimated forty-six cubic metres of rainwater a year.

The oversight of Venice's wells came under several authorities, each staffed by elected officials drawn from the city's patrician elite and a smaller number of "citizens". From 1480 the technical and construction side was overseen by what we might call the city's public works department, the Provveditori di Comun, as part of their jurisdiction over the mainte-

\footnotetext{
${ }^{7}$ In Venetian use, building addresses are indicated by their sestiere, or district, followed by a number, which can reach into four figures.
} 
nance of streets, squares, bridges and embankments (Zaggia 2004). The actual water they contained - water quality - was the responsibility of the health officials, the Provveditori alla Sanità, as we have seen. ${ }^{8}$ Because the "health" of the cisterns was also affected by the dense network of saltwater canals and the waters of the lagoon more broadly, they also came under the jurisdiction of the Magistrato alle Acque. ${ }^{9}$ There were two main threats to the functioning of the cisterns, both caused by water: either too much or too little (Constantini 1984, p. 19). Too much, in the form of exceptionally high tides like the one denounced by Raimondo, would cause salt water and refuse to flood into the cisterns. They would then have to be pumped out and fresh water repeatedly poured through the sand spongia around the shafts to cleanse the system of residual brackish water. Too little, during periods of prolonged drought, and the clay walls lining the cisterns would crack. Topping up the cisterns with river water was necessary to prevent this from happening and of course to ensure a supply of fresh water.

Numerous trades made the cistern-system possible. The task of digging out the space for cisterns was considered quite difficult, requiring a high level of skill to avoid landslides or even collapses of the foundations to the surrounding buildings. The city's wellmakers (pozzeri) were responsible for building, maintaining and repairing the cisterns, and formed a branch of the masons' guild (mureri). They were assisted by the bargemen who brought the sand from the Lido (the burcheri da fango), masons who were responsible for the actual masonry of the cisterns, and stonecutters (tagliapietra) for the ornamentation to the well-heads. When accessible and lockable cast-iron covers were added to the wellheads, ironmongers (fabbri) became part of the list of trades involved (Costantini 1984, pp. 15-16). This was done out of necessity, despite general agreement that keeping the wellheads uncovered, so that air and light could mix with the water, made for the "sweetest" water (Sansovino 1581, p. 143). Parish heads (capi contrada) were responsible for ensuring the public cisterns, to which they had the keys, were opened twice a day, announced by the ringing of bells. They were also tasked with fining those, like tradesmen, who drew water illegally, since the public cisterns were off limits to anyone who relied on water "for their trade or income" (Vanzan Marchini 1995, I: 334-335). Street-sweepers (nettadori, scoazzeri, cura gattoli) were engaged to sweep the paved areas around the well-heads to keep them free of filth, ensuring the drainage holes were free of debris or, just as importantly, plugging them with clay in case of very high tides (crucial for keeping salt water from entering the cisterns and spoiling the water). Water-carriers (bigolanti) sold water from the cisterns by the bucket to private customers and workplaces.

One essential supplement to this list of cistern-related occupations were the city's burchieri acquaroli, a designation that reflects the dual nature of their occupation as watercarters and bargemen. ${ }^{10}$ Because Venice's supply of rainwater was not always enough, as Sanudo pointed out, from the city's early days the watermen were responsible for bringing in supplies of fresh river water - the second key element of the Venetian cistern-system. The

\footnotetext{
${ }^{8}$ This derived from their responsibility for public health, protecting the city against infectious diseases like plague and overseeing the activities of medical practitioners.

${ }^{9}$ Founded in 1501, this magistracy had oversight of all of the waters of the lagoon and soon became one of the central institutions of the Venetian state. From 1565 an inheritance tax of $5 \%$ on the transmission of goods was payable to the Magistrato alle Acque, known locally as "paying the waters" (pagare l'Acque) (Bevilacqua 1998, pp. 91-92).

${ }^{10}$ They were generally known simply as acquaroli, for which the closest English equivalent is "watermen", which could indicate both bargemen and water-carriers.
} 
acquaroli represent an aquatic variant of the water-carter found elsewhere in Europe, from Naples to Poland (Gentilcore 2018; Sowina 2016, pp. 400-408). ${ }^{11}$ Their important function was recognised by incorporation as a guild in 1471. It was the guild's function to maintain standards and ensure good working relationships among members. More importantly, guild status meant that, although excluded from power-in Venice, limited to patricians and "citizens", as we have seen - the watermen had an important role in implementing decisions and policy (as well as, just occasionally, resisting them in the pursuit of their own interests).

Using special flat-bottomed canal barges known as burchi, the Venetian watermen would take on water from the River Brenta at Lizza Fusina (now, Fusina, just south of Marghera) and then transport it across the lagoon, docking at places like the suitably-named Rio dell'Acqua Dolce ("Fresh water Canal", near the church of Santi Apostoli) (Tassini 1882, p. 5), before taking the water to individual cisterns. The trip took three or four hours (Porzio 1747 , p. 58). On arrival at their chosen destination, the watermen employed a series of wooden implements (bucket, crate and piping) to transfer the water to the cisterns (Fig. 2). Importantly, they poured the water not direct into the well-shafts but through the drainage holes (gattoli) in the paving grates, so that it could enter the galleries and filter through the sand and from there deposit in the well-shaft. The watermen were also required to undertake a degree of cistern maintenance, overseeing a certain number of them at their own expense,

${ }_{11}$ In Amsterdam fresh water was also transported by barge (though horse-drawn in this case), for drinking, cooking and beer brewing (Wijntjes 1982; Loen 2020, pp. 86-87).

Fig. 2 "Deficienza proveduta" (shortage rectified) by the Flemish-Italian Giovanni Grevembroch (Jan van Grevenbroeck), showing two acquaroli at work. Watercolour, late-eighteenth century (Grevembroch 1981, IV: no. 63)

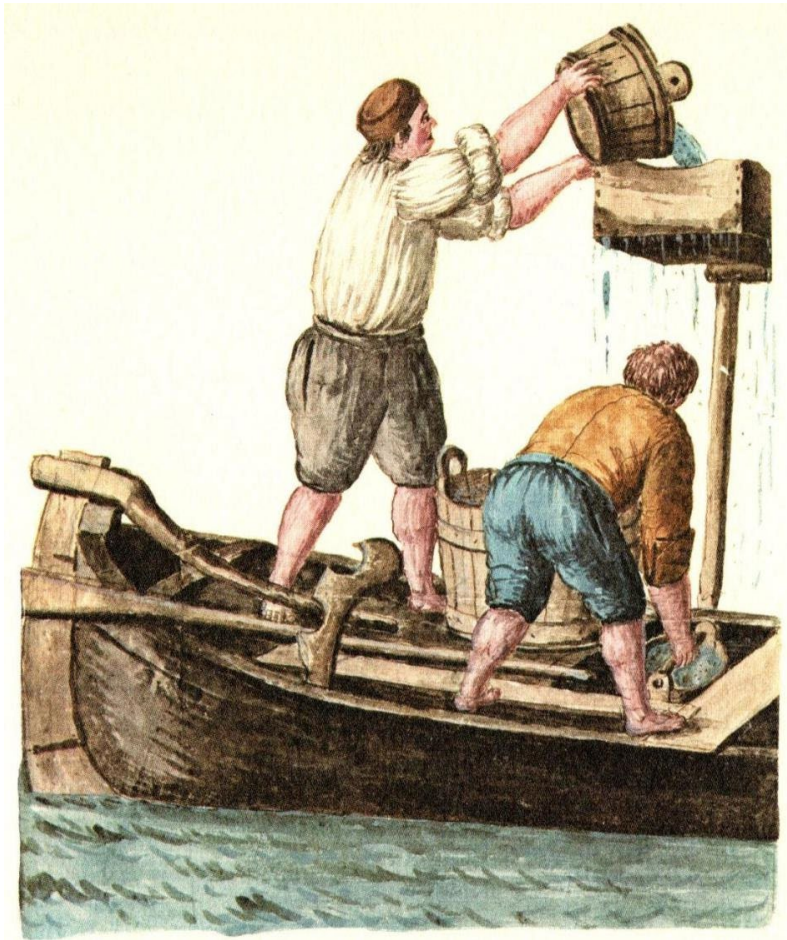


to ensure the cisterns were kept clean and rubbish-free, and to prevent tradesmen and artisans from drawing illicit supplies of water for their activities.

The watermen were kept busy transporting fresh water to Venice. For instance, over a sixteen-month period from 1 to 1597 to 31 July 1598 the guild's thirty-three registered barges made a total of 11,857 trips. ${ }^{12}$ Some watermen made the trip two or three times a day, although on average it works out to just under a barge-load per day. Since each burchio held 30 botti of fresh water (Lucchesi 1805, p. 57), or 25.38 cubic metres, this meant that the watermen transported as much as $300,930.66$ cubic metres over the sixteen months. Each load was able to completely fill an average-sized private cistern and fill to three-fifths an average public cistern, given that the volume of the average private cistern was 30 botti and the average public one 50 botti, or 42.300 cubic litres (ibid., p. 37). By 1773 the guild of acquaroli had 126 members, three of whom were receiving parish poor relief because they were either elderly or infirm (Vianello 1999, p. 775). Since the master watermen and their sons numbered only twenty-six at the time, their numbers were supplemented by other barge-men, such as the scoazzeri (night-soil bargemen). Under permission, the latter could transport water on an occasional basis and sell it retail, though with the proviso that they convey the water in wooden barrels used for nothing else (Sagredo 1856, p. 233; Grevembroch 1981, IV: no. 63; Marangoni 1974, p. 57; Vanzan Marchini 1995, I: 134).

This water was not free: during a prolonged drought in July 1446, barge-loads of water started at a base rate of 25 soldi each (Costantini 1984, p. 33). A century later, parishes, charitable institutions and the Venetian fleet paid 12 lire per barge-load (or 240 soldi), which represented a discount of $25 \%$ over the standard rate. ${ }^{13}$ And the Arsenal, Venice's all-important shipyard, not only had precedence on water deliveries but paid a further reduced rate of 7 lire (140 soldi) per barge-load (ibid., p. 86). Everyone else-from private individuals who could afford it to tradesmen who needed it for their activities (dyers, wool-makers, clothmakers, bakers, soap-makers, innkeepers, glassmakers, barbers, and so on) — paid the full rate of 16 lire (320 soldi) per barge-load. Filling up your cistern was an expensive undertaking, close to what the patrician Leonardi di Marino spent on food purchases each month (Cecchini 2020, p. 488); but then, for those who could afford it, that water would go a long way. The ability of Venice's elites to pay for this extra water led certain visitors to assume they had a preference for it; thus Fynes Moryson's remark that "the common sort use well water and raine water kept in cisternes, but the gentlemen fetch their water by boat from the land" (Moryson 1907, I: 163). Moryson was only half right in both his assertions: first of all in making a difference between "wells" and "cisterns" (when in Venice they were one and the same thing); and secondly, in not being aware that elite households had their own private cisterns (which they could of course top up whenever they wished, at their own expense).

The watermen had to recover their costs. From 1498, as a kind of tax on their operations, the health officers required the acquaroli to provide 100 barge-loads of water free to the city's public cisterns and charitable institutions (Vanzan Marchini 1995, I: 132). Thus in 1654 they were assigned eight barge-loads to Venice's hospitals, seven to various convents and monasteries, and the other eighty-five to the city's public cisterns (ibid.; Marangoni 1974, pp. 55-56). This list of religious institutions served was occasionally revised to meet changing needs, although the number of 100 remained constant until 1791, when it was

\footnotetext{
${ }_{12}$ ASVe, Archivio Pesaro, b. 43, fasc. 4, fols. 8r-9r (Molà 2010, p. 446).

${ }^{13}$ In Venetian currency, a lira was made up of 20 soldi, the latter being a money of account (Pullan 1964).
} 
reduced to 50 (Vanzan Marchini 1995, I: 135). And from 1548 the guild paid an actual tax on each barge-load of water, set at eight soldi (Costantini 1984, p. 85), or $2.5 \%$. Their costs also included payment of a toll to the Pesaro family to pump water at Fusina, which had acquired the rights to collect tolls at that stretch of water, where the River Brenta met the lagoon (Molà 2010, p. 464). During the plague of 1423, in order to ensure the supply of cistern water remained pure, the authorities had explicitly prohibited the transport of any other fresh water (Costantini 1984, p. 29). The tolls were very profitable, since everyone travelling by river from Padua to Venice had to pass over the docks located there. Montaigne, "somewhat disappointed" by Venice and with little to say about it, was nevertheless impressed by the docks at Fusina. "Here they bring ashore all the boats with machinery and pulleys worked by two horses after the fashion of an oil mill. They move their boats by means of wheels placed underneath, which run along planks and thereby convey them over to the canal which runs into the sea on which Venice is situated" (Montaigne 1903, vol 3, pp. 13-14, 16). It was here that Montaigne met with an interesting sight, which he recalls while narrating his onward trip to Ferrara.

I forgot to remark that the day we quitted Venice we met a number of boats filled with fresh water, the contents of a boat being worth a crown in Venice, where it is used for drinking or dyeing cloth. After we got to Fusina we saw how the water was raised from a stream and turned into a canal by means of a wheel kept going without ceasing by horses. The boats aforesaid lie beneath the mouth of the canal and are there loaded with water (ibid., p. 35).

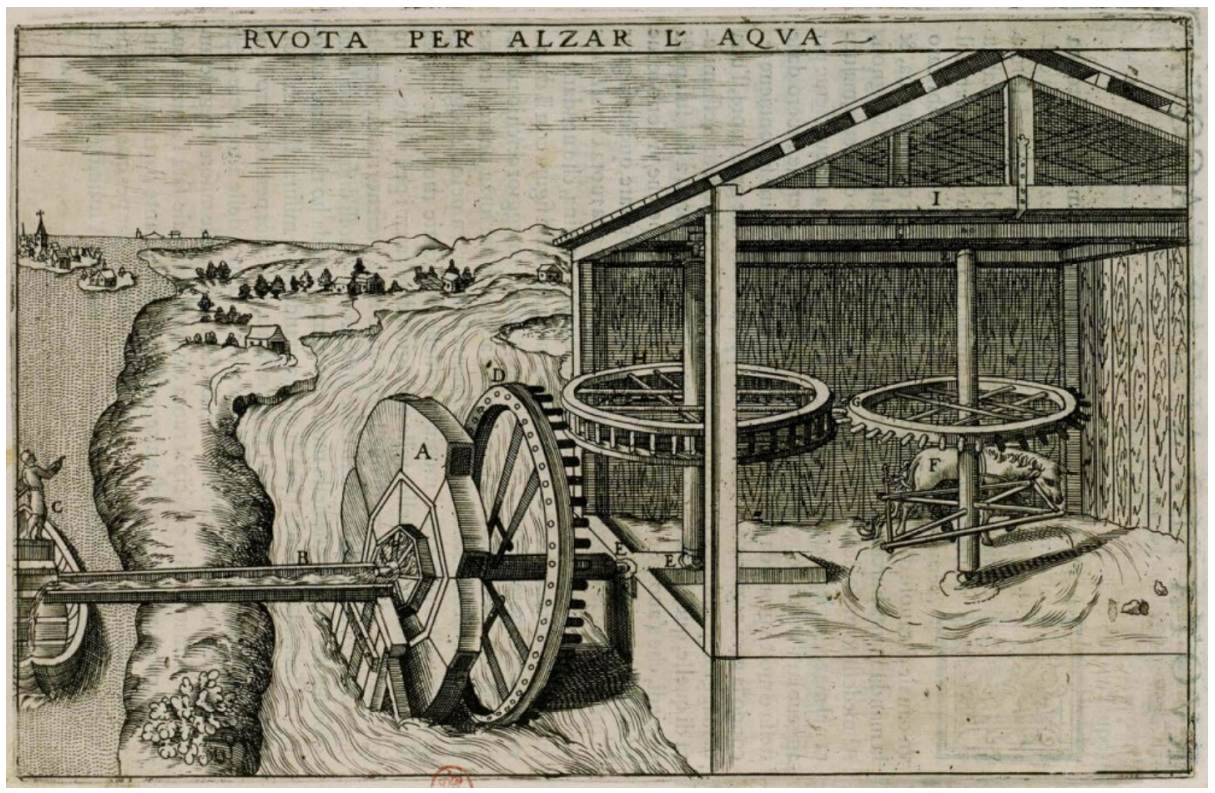

Fig. 3 "Ruota per alzar l'acqua" (wheel for raising water), illustrating the scene described by Montaigne in which a Venetian water-barge complete with standing acquarolo, moored on the lagoon side, is being filled with fresh water from the canal (Zonca 1607, p. 61) 
A few years after Montaigne's visit, the watermen complained of the "desolate" state of the pumps and of having to fill their barges with their own hands. In 1588 they petitioned the authorities to be allowed to construct and operate their own "edifice" to pump water into their barges. They stressed the important contribution they made to the city, "both for the ordinary use and necessity of the inhabitants for drinking as well as for the support of dyers, and the uses of trades, soap-makers, bakers, the public pesthouses, and the Arsenal and many other places". ${ }^{14}$ Like other boatmen active in Venice-who "collaborated with the construction of the social order" but who "did not hesitate to go against the patricians to defend their positions and economic prerogatives" (Quillien and Rivoal 2020, p. 211) — the acquaroli could be quite savvy and were well aware of their own importance within Venice's cistern-system. Ensuring its continued functioning required the efforts of a range of actors. And while the constituent elements of this system remained more or less constant throughout the early modern period, the technology behind it evolved and adapted, within the constraints of the period.

\section{Sanitation and the maintenance of water quality}

The physician and long-time Venetian resident Tommaso Rangoni had no doubts about the quality of the waters of the city's cisterns: "agreeable, without taste and colour, indeed sweet and limpid and light they are drunk. With them bread is made, all foods are cooked and prepared, so that they are healthy, excellent and well-suited to preserving life" (Rangoni 1577, pp. $7 \mathrm{r}-7 \mathrm{v}$ ). More than two centuries later the hydraulic engineer and employee of the Magistrato alla Acque Pietro Lucchesi said much the same, judging them "limpid, sweet and healthy" and perfectly suited to "the uses of life" (Lucchesi 1805, p. 30).

Far from being ignorant of notions of water purity, early modern Europeans were careful connoisseurs of the virtues and vices of water, when judged according to their own understanding and knowledge (Gentilcore 2020). In a book published around the time of Raimondo's, the physician Teodoro Guainerio discussed the different types of water, insisting how it was up to doctors (like him!) to determine which were best for human health, but in fact echoing ideas about freshwater inherited from the ancients, particularly Hippocrates. The first criterion was that water should be "airy" in quality, other qualities such being clear, thin and light all following from this. Rainwater met these criteria best (Guainerio 1577, pp. 16-17). Filtration ("purgation") and stillness only improved on these qualities. For the Roman-born Francesco Sansovino the waters of Venice's "wells" were "healthier and easier to digest than flowing waters because of their crudeness" (Sansovino 1581, p. $140 \mathrm{v}$.). In fact river waters were generally judged to be heavy and hard to digest, because of the soils over which they flowed, even assuming they were distant from polluting trades. So what then of the copious amounts of water the acquaroli brought from the River Brenta in barges and poured into the cisterns to supplement rainwater supplies? Fortunately for Venetians, Renaissance physicians were flexible, ever ready to approve of local practices and preferences, which extended to local water resources. Thus the Paduan physician Michele Savonarola extolled the waters of the Brenta for drinking purposes, because of their health-

\footnotetext{
${ }^{14}$ ASVe, Collegio, Risposte di dentro, filza b, no. 196, 16 February 1587 (=1588) (Molà 2010, p. 466). Theirs was only one in a long series of pump designs submitted to the authorities (Costantini 1984, pp. 61-65; Molà 2010).
} 
giving and long keeping properties (Savonarola 1902, p. 8), even if elsewhere he regards river water as less than ideal (Savonarola 1515, p. 45r.). On top of this, Venetians only used this water after it had been "purged" in their "wells", so no infirmities were associated with it, according to the physician and Venetian resident Andrea Marini, writing in 1559 (Marini 1923, p. 9).

Visitors were also impressed. Coryat wrote of the two large ornate "wells" in the courtyard of the ducal palace, which "yeeld very pleasant water. For I tasted it" (Coryat 1905, I: 338). Visiting Venice three-quarters of a century after Coryat, in 1683, the military doctor Luc'Antonio Porzio concurred with his opinion of the water from the ducal palace cisterns, judging it "salutary and pure" (Porzio 1747, p. 55). But he shifted the emphasis to the crucial role played by filtration. Because the cistern waters pass through sand, "many of their bad qualities are corrected, especially their taste and smell of pitch and tar"- the result of "three or four hours" of contact in the "small pitch'd boats" used to bring in the additional water (ibid., p. 58). However, Samuel Sharp, an English traveller who can be trusted to bring a critical eye to just about everything he experienced in Italy, highlighted the variable quality of the sand lining the cistern: "as every housekeeper thinks his well better furnished than that of his neighbour, one may conclude that some of them are porous and do admit more or less saltwater into them. The frequency of diarrhoeas in this city is another argument that the water they drink is purgative" (Sharp 1767, p.30). ${ }^{15}$

When it came to protecting the cisterns, exceptionally high tides were a constant worry. Writing his short treatise for the Venetian authorities at the end of 1559 - and with the high tides of the previous November in mind, as well as flood events in previous years (1535, 1542,1549 ) - Marini warned of their dire effects. They filled ground-floor rooms with a mixture of saltwater and waste, which led to a "putrefaction of the air and spoiled the waters in the cisterns, from which originate very serious illnesses" (Marini 1923, p. 6). Keeping the cisterns clean and the water uncontaminated was a constant concern. In March 1631, following the plague epidemic of the previous year, the heads of the Santa Croce district charged three priests of San Simeon Grande with having buried hundreds of plague victims both in and around the church, so close to the public cistern as to risk infecting it. The result was an unbearable nausea and foulness such that those people who entered the church to participate in the divine services left with headaches and fear of much worse". ${ }^{16}$ The charges were brought initially brought before the Council of Ten, one of the city's main governing bodies, before being passed on to the Provveditori alla Sanità. Because cistern maintenance and repair was so complex, labour-intensive and costly, cisterns judged not fit for drinking were often turned to other uses (Lucchesi 1805, p. 37).

Outdoor paved surfaces had to be kept clean and free of debris if they were to serve for rainwater capture. As early as 1325 it was forbidden to deposit waste and "sweepings" ("immonditias et scopaturas") in the vicinity of the well-heads (Giormani 2010, p. 329). Each parish head (capo contrada), elected once a year, was tasked with ensuring the cleanliness of the squares and streets in his parish, fining offenders 10 lire (fines which formed part of his income). He also oversaw the activities of street-sweepers (Vanzan Marchini 2009,

\footnotetext{
15 The French visitor François Maximilien Misson had likewise concluded that the city's water "is almost all very bad"- - but, then, he also made the mistaken distinction between wells ("there are but two or three good for any thing") and cisterns ("the best water is the rain-water which some private persons reserve in cisterns") (Misson 1695, I: 185).

${ }^{16}$ ASVe, Consiglio dei Dieci, Criminal, reg. 46-49 (Ulvioni 1989, pp. 111-112).
} 
pp. 124, 125). The latter, hired by their local district (sestiere), also emptied the bins (caselle delle scoazze) located throughout the city into which people were meant to deposit their rubbish and human waste, and were tasked with ensuring the gattoli were kept open and clean, so that rainwater could flow into the cisterns and disease-causing rubbish was not allowed accumulate. Indeed, in his 1785 depiction of the street-sweeper, in his series of etchings of some of the city's itinerant trades, the printmaker Gaetano Zompini refers to him as a cura gattoli, as if to stress the importance of this function (Zompini 1785, no. 38). As stipulated by the Magistrato alle Acque in 1558, street-sweepers were to clean the streets four times a month and would only be paid once their efforts had been undersigned by the parish captain. In 1609 , evidently unsatisfied with the existing state of affairs, the same magistracy tasked the officials of the confraternities of the Venerable Sacrament with checking the cleanliness of the streets and issuing a signed declaration to the street-sweepers, legislation that was renewed in subsequent decades (Tentori 1792, pp. 214, 216).

Trades were responsible for clearing the waste they produced, like the vegetable-sellers (erbaioli) who in 1522 pledged before the health officers to pay "Giacomo the bargeman"

Fig. 4 A street-sweeper, with his spade, broom and barrow, as depicted in a series of etchings of Venetian itinerant trades by Gaetano Zompini (Zompini 1785 , no. 38)

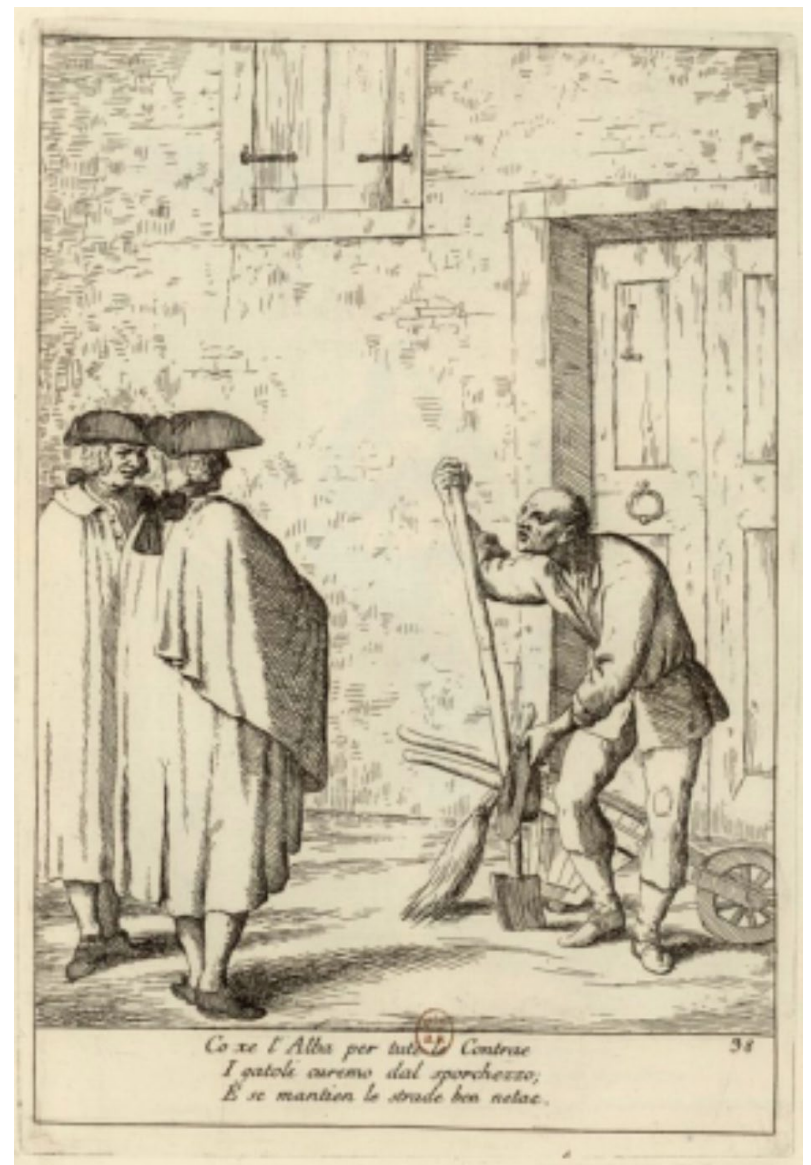


three ducats a year to clear away their rubbish. ${ }^{17}$ As of 1768 , shopkeepers were also required to keep a bowl of "fresh clean water" outside their shops for dogs (Vanzan Marchini 1995, I: 323). Fishermen were obliged to empty, at their own expense, the four waste bins located on the Fondamenta Nuove, the three in Piazza San Marco and the two at the Rialto fish market (Tentori 1792, p. 216). Every shopkeeper was to sweep the street in front of their shop or face a possible fine of 25 lire and prison; from 1554 city magistracies were obliged to do the same in front of their buildings (Vanzan Marchini 2009, p. 123; Tentori 1792, p. 214). Tradesmen, shopkeepers and private citizens alike, when judged responsible for blocking or damaging the gattoli by the health officials, were obliged to clean, maintain or repair them (Vanzan Marchini 2009, p. 127).

The rubbish and night soil accumulated by the street-sweepers was emptied into waiting waste barges (burchielle da scoazze), the night soil men (scoazzeri) sounding their horns as they passed and transporting the waste to farms for use as manure. In 1657 the health officers decreed that this should only be done at night, when people would be at rest with their shutters closed, because of the bad smells. ${ }^{18}$ The scoazzeri were also responsible for clearing the filthy sludge that encrusted the canal banks. This was in fact part of a rudimentary underground sewer system, unusual (if not unique) in pre-modern Europe. Many Venetian houses were equipped with an indoor, upstairs privy closet, known as a necessario, into which chamber pots would be emptied. ${ }^{19}$ The contents travelled from the privy down a network of earthenware pipes built into the interior walls of the building, and then continued underground with enough of a slope for the contents to be deposited into the nearby canal, via a small, square opening in the canal bank (Gianighian 1983). This canal opening was located just above the average tide water line, so that it remained dry at low tide and was cleaned out at high tide. The earliest legislation in this regard dates from 1315, when a decree passed by the Maggior Consiglio stipulated that houses with waste pipes opening on to streets should ensure they were disabled, so as to keep streets free of waste. Instead of this, houses located along canals should discharge their human waste direct into the water, via underground pipes; whereas those located further away should have their own waste pits, to be emptied periodically, at night. As of 1498, the health officials reiterated this regulation, with offenders to be fined 25 lire, with the fine going to the accuser (to encourage accusations). During the sixteenth century the health office was kept busy ensuring offenders were prosecuted, noblemen and commoners alike (Vanzan Marchini 2009, pp. 135-136).

In Venice, as in other towns and cities of early modern Europe, "sanitation" revolved around the provision of drinking water, the removal of waste and clearing of urban ditches and nearby watercourses (Jørgensen 2010a, p. 303). The issues may have been the same, but Venice's unique configuration made their practice slightly different. In theory at least, the action of the tides in carrying away raw sewage should have made Venice one of the cleanest cities in early modern Europe. Venice was "as designed for cleanliness as any Dutch town”, commented Johann Wolfgang Goethe during his visit in October 1786. It had well-paved streets and squares, complete with gutters which carry the water off into covered drains, the evident "police regulation" according to which "people sweep the rubbish into

\footnotetext{
${ }^{17}$ ASVe, Provveditori alla Sanità, Notatorio, reg. 726, fol. 46r (Vanzan Marchini 2009, p. 123).

${ }^{18}$ ASVe, Provveditori alla Sanità, b. 741, 14 May 1657 (Bamji 2007, p. 179).

${ }^{19}$ I have opted for the English word "privy" to translate the Italian necessario, which normally referred to a simple wooden seat with a hole cut out of it, located inside the house and suspended over a cesspit which might be shared between two or more houses (Jørgensen 2010b, pp. 10-13; Skelton 2016, pp. 27-29).
} 
corners", with "large barges stopping at certain points and carrying the rubbish away", and other "technical devices". And yet, Goethe concludes, "as I walked about I was struck by the uncleanliness of the streets" (Goethe 1970, p. 80). ${ }^{20}$

Even if we no longer regard early modern European towns as being the unregulated "open sewers" of popular myth, human excrement was generally left in dunghills in the streets or in cesspits, either to be carted away, swept up or washed away by the rain in open sewers (Skelton 2016), pp. 1-19). Rome was typical in making used of an eclectic mix of operations, including a few of its ancient sewers, without great success (Sansa 2006; Long 2018, pp. 43-62). The action of the tides should also have made Venice among the healthiest too, at least in contemporary perceptions, since a constant in Renaissance disease theory was that stench corrupted and putrefied the surrounding air, producing poisonous and pestilential miasmas.

At a time when the presence of filth was linked to foul odours and to disease-causing miasmas, Venice's air was judged "very wholesome, whereof the Venetians bragge, that it agrees with all strangers complexions, by a secret virtue, whether they be brought up in a good or ill ayre, and preserveth them in their former health" (Moryson 1907, I: 164). In 1559 Marini wrote of how the saltwater tide cleansed the city's canals twice a day, purging them of excrements and rendering the surrounding air "most healthy". But then Marini adds: at least it used to do so, but the shrinking of the lagoon had lessened its positive effects (Marini 1923, pp. 3, 6). Indeed, according to Thomas Coryat, who visited Venice in 1608, the canals "carryeth away all the garbage and filthinesse that falleth into them from the citie, which by means of the ebbing and flowing of the water, is the sooner conveighed out of the channels, though indeede not altogether so well, but that the people doe eftsoones [soon afterwards] adde their owne industry to cleanse and purge them" (Coryat 1905, I: 313). Clearly, the system worked best when the tidal ebb and flow was regular. However, as denounced by Raimondi, extraordinarily high tides had the opposite effect, flooding city squares and streets (and wells) with this refuse. And the other extreme, drought and low tide levels, brought its own problems, according to Sharp, who noted that "the canals, at low water, are often, in summer, very offensive, perhaps unwholesome" (Sharp 1767, p. 30). ${ }^{21}$

Activities to keep the system clean came up against a range of challenges. Just occasionally the corpse of a murder victim might find itself cut up into pieces and disposed of in the cisterns and canals, as happened 1781 as the result of a crime of passion (Passarella 2017, p. 20). People also fell into wells while drawing water or by suicide (Bamji 2020, p. 35). On less graphic lines was the urge to throw rubbish into the streets and canals, a practice that emerges from repeated legislation against the practice. The fine for throwing rubbish into the canals was five times higher than throwing it into the streets, as a decree issued in 1536 by the Savi ed Esecutori alle Acque demonstrates. ${ }^{22}$ A report compiled in 1568 by one their number for his colleagues, Dolfin Valier, bemoaned the total lack of respect for the laws,

\footnotetext{
${ }^{20}$ Goethe mistakes the guttering and drainage holes of the cistern-system for a means of carrying away excess water.

${ }^{21}$ The "perhaps" is probably superfluous. Venice's present-day sanitation system is not all that different. Rubbish is collected door to door every day and carted away by barge. Aside from tourist accommodation and public buildings, which must have septic tanks (emptied by barge on a regular basis), much human waste still goes into the city's canals; not surprisingly, analysis has demonstrated a high level of "fecalisation" (Vazzoler 1999).

${ }^{22}$ ASVe, Savi ed Esecutori alle Acque, reg. 334, fols. 68r-69v, 17 February 1535 (=1536) (Wheeler 2007, p. 36).
} 
with officials meant to enforce them actually complicit in their being ignored. ${ }^{23}$ In 1528 the health officials (Provveditori della Sanità) had to remind Venetians that it was forbidden to "abuse the footmen, boatmen and officials of the said office either in words or actions". ${ }^{24}$ From a hygiene perspective, action taken by the health officials during the $1530 \mathrm{~s}$ shows ongoing problems controlling waste. Dozens of parishes and courtyards were blighted by people emptying their refuse direct from their balconies on to streets or courtyards. ${ }^{25}$ But given the nature of the source, denunciations, it is difficult to gauge whether this practice was the exception or the rule. Thus in June 1629 Sebastiano Contarini was found guilty of having "tossed a pitcher of urine out of the windows on to the Riva degli Schiavoni, wetting three sailors who were passing by", while having a meal in a tavern with some friends (Ulvioni 1998, pp. 116-117). The three years Contarini was to spend in prison as a result must have been due more to the ensuing brawl than the offence of pouring the contents of a chamber pot on to the paving, but it does give an idea of what might take place. Portions of fines issued by certain city tribunals went towards the maintenance of the canals, as did occasional taxes. In 1533 the Venetian Senate taxed all the magistrates, notaries, and other legal professionals practising in the city in order to pay for the costs of excavating the canals so that the waters "could flow everywhere throughout the city, on which depends the health of all inhabitants". ${ }^{26}$

\section{Cisterns and fresh water use in daily life}

In the towns and cities of pre-modern Europe, fresh water was in limited supply (Roche 1984) and Venice was no exception. Under normal circumstances, according to Lucchesi, the average daily amount of fresh water available for drinking and cooking was one secchio (10.7 L) per person (Lucchesi 1805, p. 58; Giormani 2010, p. 342 n.). But-and this was also typical throughout early modern Europe - this supply was not evenly distributed across Venetian society. Wealthy patricians would have had their own independent supply, from one or more cisterns in palace courtyards, for the use of their extended households. The same was true of convents and monasteries, although they sometimes granted access to surrounding residents. Professionals and artisans might have benefited from either their own or shared private indoor cisterns or located in private courtyards. But many houses in the city lacked fresh water at all, their residents having to rely on water drawn from public cisterns, which might be located at some distance away. In 1537 one widow lamented that although she owned her ground-floor flat (in Secco Marina), with her four young children "if I had to pay rent for it I wouldn't live there because it has no water of any sort and we suffer greatly". ${ }^{27}$

What about Venice's Jews, from 1516 confined to the Ghetto where, by the mid seventeenth century, population density was two to four times higher than in the rest of the city (Calabi et al. 1996, p. 148)? Despite the medieval stereotype of the Jews as poison-

\footnotetext{
${ }^{23}$ ASVe, Savi ed Esecutori alle Acque, reg. 270, fols. 11v-12v (Wheeler 2007, p. 37).

${ }^{24}$ ASVe, Provveditori alla Sanità, Notatorio, reg. 727, fol. 157v (Judde de Larivière 2020, p. 80).

${ }^{25}$ ASVe, Provveditori della Sanità, Notatorio, reg. 727 (Wheeler 2007, p. 37).

${ }^{26}$ ASVe, Provveditori alla Sanità, reg. 12, fol. 74 (Vanzan Marchini 2009, p. 117).

${ }^{27}$ ASVe, Dieci Savi alle Decime, Redecima 1537, b. 95, no. 719 (Gianighian 1982, p. 570).
} 
ers of wells and plague-spreaders (Cusumano 2007; Bamji 2007, pp. 181-182), none of this reared its ugly head in Venice during the plague of 1575-77. This was due, I think, to three factors: a relatively tolerant stance towards the activities of the numerous Jewish medical practitioners in the city, including during the plague period (Vanzan Marchini 1979, pp. 152-153); the practical oversight, organisation and management of the cistern-system, which responded quickly to threats (such as that brought to the attention of the authorities by Raimondo); and the fact that actual persecutions of Jews for well-poisoning in time of plague originated from the ruling elites, during the first wave of plague in Europe, the Black Death (Cohn 2007), persecutions which did not happen in Venice. Nor was anyone else-beggars, foreigners, witches - blamed. Venice witnessed none of the conspiracies or accusations of plague-spreading by means of poisonous substances experienced elsewhere, either in the $1570 \mathrm{~s}$ or during the successive plague pandemic of 1630 (Naphy 2002, pp. 128-157; Pastore 2007; Ulvioni 1989, p. 58), which, in any case, did not involve wells but the suspected transfer of plague via an impregnated "grease" to household objects such as clothes, fabrics or bedlinen.

We can gain an insight into water access in the Venetian Ghetto during "normal" times through internal disputes. With so many people living in such a confined space, it was inevitable that many of these were of a civic rather than religious nature, regarding matters of taxation, property and water provision. While the city's Jews were obliged to live in the Ghetto they were not permitted to own property: a 1587 legal decision reaffirmed that the landlord of all of the Campo del Ghetto Novo was the (Christian) da Brolo family. Although Jews could not own property outright, they were granted long-term tenancies which allowed them to make substantial modifications and improvements in order to sub-let properties (at a profit). This was known locally as the jus casacà (from the Hebrew word hasakah, possession), according to which Jewish possession and management of property in the Ghetto in effect masked Christian ownership (Calabi et al. 1996, pp. 44-47, 160-162).

This included cisterns. In 1605 the da Brolos rented out the access to three cisterns located in the Campo del Ghetto Novo to the Fraterna Talmud Torah, "for as long as they shall be in the Ghetto", for 24 ducats a year (Lemire 2001/2, pp. 117-118). The Fraterna combinied devotional and charitable functions, with an emphasis on religious education (Ioly Zorattini 1968). The Fraterna sub-let the cistern access to a group of local water-carriers who sold the water door-to-door by the bucket (secchio). The arrangement comes to our attention because in 1641 Marco da Brolo objected to the profit the Fraterna made sub-letting the wells to the water-carriers, totalling 114 ducats (from a rent of 138 ducats). Da Brolo argued that wells could not be subject to material improvements in the way of other property and so the Fraterna should not be permitted to profit from sub-letting them. The decision went in da Brolo's favour and a few years later the Fraterna is recorded as paying him a rent of 111 ducats (Lemire 2001/2, pp. 120-121). The case illustrates the ongoing ambivalence of Jewish life and property use in the Ghetto. While the Jewish inhabitants regarded this space as their own, including use of its three wells, as managed by their Fraterna Talmud Torah, the Venetian authorities also regarded it as the private property of Christian owners - ownership that extended to water rights.

In the Ghetto as elsewhere, well-heads-occupying prime positions in the squares, streets and courtyards - were a focal point for sociability, "an extension of the domestic space" (Casellato 2014). As we have seen, the public cisterns were opened twice a day, to the ringing of a bell, when women and maidservants of the local parish would come to fetch 
water for their households. Although first performed in 1873, the play Le serve al pozzo (Maidservants at the well), by the Venetian playwright Giacinto Gallina, seems to hark back to the eighteenth-century works of Carlo Goldoni (Gallina 1924). In the play, the well-head occupies centre stage, with the main characters acting out their lives and loves around it, while coming to draw water twice a day, with the parish head (capo contrada), responsible for unlocking the iron lid, nosily looking on. By Gallina's time this scene of women at the well-head was a stereotypical element of the Venetian "picturesque", represented in dozens of picture post-cards and photographs printed for tourist consumption, but was of course still lived reality for many inhabitants of the city (and would continue to be so long into the twentieth century, decades after piped water arrived in 1884). Paradoxically, some of the very well-heads that were the site of this sociability were at the same time being sold off to foreign collectors, eager to re-create a slice of the Venetian picturesque in their own gardens back home (Tüskés 2010).

Domestic water was part and parcel of daily life. In a sixteenth-century case held before the Venetian Inquisition, a certain Clara recounts how she suspected her neighbour Angela of dubious behaviour, first spying on Angela from her balcony and later sending a manservant to ask Angela for water, as a pretext to enter her house (Chojnacka 2001, p. 68). Venetian probate inventories from the same period reveal the ubiquity of household implements to fetch, store, ladle out or wash with fresh water: large earthenware jugs for storage; copper buckets and ladles for drinking and cooking; brass pitchers, iron "fountains" and basins for washing (Palumbo Fossati Casa 2013, pp. 34-35, 75, 117-118, 179). They were variously listed as being in the kitchen, entrance hall and/or bedroom at the time of the notarised inventory, in line with their function. The lawyer Gaspare de Zanchi kept a "large water pitcher" (uno pitter grande da acqua) in a ground-floor storeroom, which held 20 secchi of water, or $214 \mathrm{~L}$, according to an inventory of 1582 (ibid., p. 119). This sort of large water container must have been common in better-off households without easy access to their own cistern. The patrician Donato da Lezze had no such worries, with a well-head of his own in a small courtyard, where laundry was also done, to judge by the implements recorded there

Fig. 5 "Donne al pozzo" (women at the well), post-card photograph by Venetian publisher-photographer Ferdinando Gobbato, early twentieth century. Note the presence of the capo contrada, dominating the scene

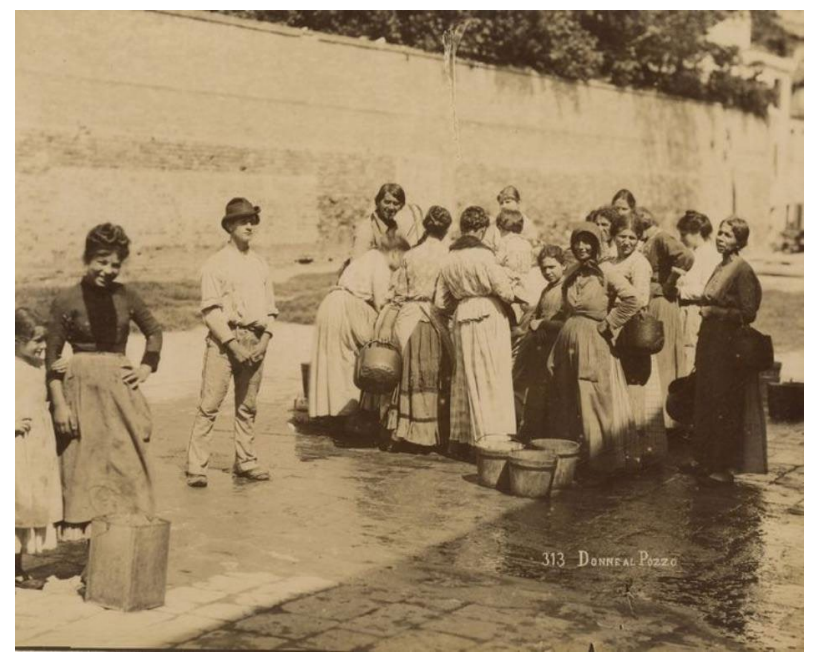


in his inventory from 1582 (ibid., 248). ${ }^{28}$ Domestic water implements even found their way into popular magical rituals, as when Oliva "la Grega" taught a certain Andriana to read "signs" in the water inside of an inghistera (flat-bottomed jar) in order to locate a lost ring. ${ }^{29}$

A crucial implement not recorded in the probate inventories is the bigolo, a wooden halter or harness worn over the shoulders to carry two buckets of water, part of the demanding task of fetching water each day from the nearby cistern, invariably done by women. The Venetian word bigòlo was already being used in 1410, when a nobleman, Niccolò Barbo, on finding out his Tartar slave Bona was pregnant, "became infuriated and beat her with a shoulder harness used for carrying water": "cum bigolo ab acqua" in the trial records. ${ }^{30}$ Tartar slaves like Bona did domestic work in Venetian households - cooking, cleaning, laundry, carrying water, buying food - and so Barbo made use of the likeliest weapon to hand (Barker 2014, pp. 86-87, 105). (The beating only came to light when Bona subsequently attempted to poison her master with arsenic.)

In its intended use, the implement was vital enough to give its name to an occupation, the bigolante or water-seller (Migliorini 1936, p. 71). In most Italian towns, as in much of Europe, the water-seller (acquaiolo in Italian, with regional variants) — a (usually) itinerant seller of (usually) small quantities of water-was a fixture of daily life. Venice was unique in dividing this trade into two quite different specialisms: those who brought in fresh river water by boat, the acquaroli, and sold it by the barge-load (wholesale), discussed above, and the itinerants who went about the city on foot selling water by the pail (retail), the bigolanti. The retail rate for a secchio of water (10.7 L) was pegged at half a soldo (Costantini 1984, p. 86). Not much for a patrician like Leonardo di Marino, for whom a soldo would purchase a pair of hose, some honey or candied fruit at the market, items that represented only a small fraction of his purchases on food and clothes (Cecchini 2020). Bearing in mind that during the early modern period the poorer the person the higher the proportion of expenditure dedicated to food and drink, the purchase of drinking water in this way was thus something of a luxury.

The bigolanti were mostly, though not exclusively, women. As domestic workers, they had no guild (unlike their male counterparts, the acquaroli). The earliest pictorial representation appears in a series of etchings of sixty Venetian itinerant trades by the printmaker Gaetano Zompini (1785). The "porta bigolo con acqua" (bigolo-carrier with water) is number 24: she is depicted simply clothed and barefoot, stepping down from the well-head bearing the tell-tale harness over her shoulders, supporting two copper buckets full of water, into one of which a boy is looking. In the background a man is bent over the well-head, perhaps the parish head responsible for opening and closing it each day. Below the image are the verses: "With this harness I carry, for a bezzo a bucket, / Water to workshops, to those

${ }_{28}$ To have one's own cistern, with enough water for laundry as well as other uses, was certainly a luxury. As noted above, washerwomen (along with other trades) were prohibited from taking water from the public cisterns. The Venetian playwright Carlo Goldoni-who was both a great observer of daily life and who gave great visibility to female household occupations in his plays (Plebani 2016) - has his young laundress Smeraldina say: "You earn little being a washerwoman these days; the money goes in washtubs and soap, and you even have to pay for the water!" (Goldoni 1738, I:13). Like many of the city's water-sellers (bigolanti) and female domestic servants, laundresses were often from Friuli (Grevembroch 1981, III: 74-75; Wolff 2012 , p. 113). When it comes to water-related occupations, laundresses would merit further study, as studies of early modern Rome suggest (Rinne 2001/2; Lilli 2008).

${ }^{29}$ ASVe, Sant'Uffizio, Processi, b. 72, no. 2, doc. 12, 1618 (Chojnacka 2001, p. 59).

${ }^{30}$ ASVe, Avogadori di Comune, Raspe, reg. 3646, fols. 84v.-85r. (Romano 1996, p. 52) 
without a well at home / It is very fresh and as clear as a mirror". The bezzo was equivalent to half a soldo. The well-head is a simple brick affair, unlike many of the city's ornate well-heads made of Istrian stone, and the bigolante is the only of the itinerant tradespeople depicted barefoot, perhaps to indicate low status and poverty. ${ }^{31}$

Like the stereotypical scene of Venetian women at the well-head, by the nineteenth century the bigolanti had become an element of "Venetian colour" (Boito 1876). By this time they were invariably described as being young women from Friuli, but most likely had been for centuries: part of a substantial migration from this poor mountainous region into the city, to work in heavy trades and domestic service (Wolff 2012, pp. 108-114). These female water-carriers are represented with their bigolo over their shoulders in front of a well-head-, either singly or in groups, in photographs and post-cards for the consumption of visitors, which became quite a lucrative business in the second half of the nineteenth century (Roncaglia 2009). In prose form, similar representations found their way into travel literature,

\footnotetext{
${ }^{31}$ A second bigolante is depicted in the background of another scene, representing a pedlar of odd fruits, vegetables and brooms (Zompini 1785, no. 45). He is a man this time, well-shod, ascending some steps with his harness and two buckets.
}

Fig. 6 A Venetian bigolante, as depicted by Gaetano Zompini (Zompini 1785, no. 24)

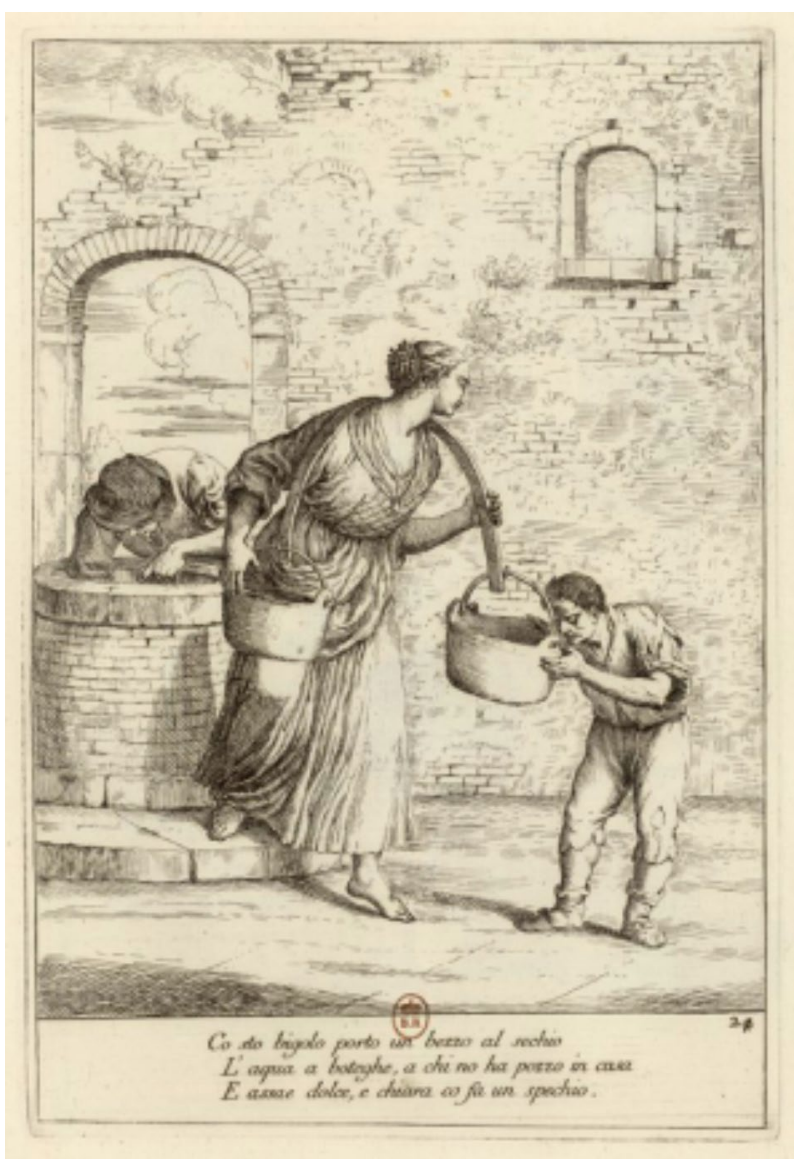


as in the following passage by William Howells, resident in Venice 1861-65 as US consul, recounting his experiences "housekeeping in the city":

But there were some things which must be brought to the house by the dealers, such as water for drinking and cooking, which is drawn from public cisterns in the squares, and carried by stout young girls to all the houses. These bigolanti all come from the mountains of Friuli; they all have rosy cheeks, white teeth, bright eyes and no waists whatever (in the fashionable sense), but abundance of back. The cisterns are opened about eight o'clock in the morning, and then their day's work begins with chatter, and splashing, and drawing up buckets from the wells; and each sturdy little maiden in turn trots off under a burden of two buckets, one appended from either end of a bow resting upon the right shoulder. ... The bigolante comes every morning and empties her brazen buckets into the great picturesque jars of porous earthenware which ornament Venetian kitchens; and the daily supply of water costs a moderate family about a florin a month (Howells 1883, pp. 94-95). ${ }^{32}$

In pre-modern Venice, regardless of one's economic means, water was a limited good. A cistern (whether public or private), a domestic water jar located in the kitchen, a water

${ }^{32}$ Not exorbitant, given that an entire flat might cost 400 florins, according to Howells.

Fig. 7 Albumen print of a bigolante by photographer and optician Carlo Ponti, c. 1870, one of many he produced for the Venetian tourist market (Ponti 1870)

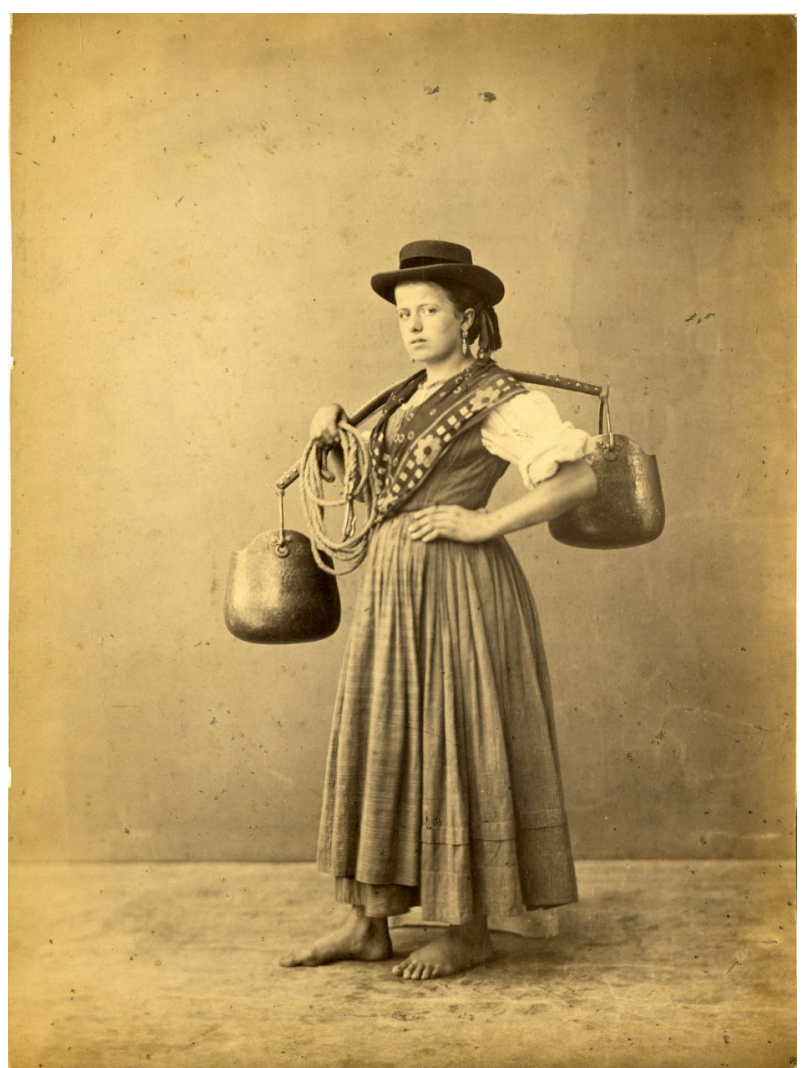


bucket and ladle: all had a limited capacity. Of course, in this hierarchical society wealth made supply less of a pressing concern; but water did not flow freely for anyone in Venice. Did this make for a different attitude towards water consumption and management than elsewhere, say, cities supplied by rivers or aqueducts? Or was it simply a difference of degree, given that water was everywhere in pre-modern Europe a limited resource? It is difficult to gain an insight into how Venetians managed their water consumption from day to day, as this necessity was a taken-for-granted fact of life and not generally remarked upon. Even with access to a private cistern, as in the case of an elite household, the amount of water available to the household was strictly dependent on the cistern's volume, the amount of rainwater that fell and could be captured (minus water loss), the number of people in the household and how much water they used, and whether they had access to water from any other sources.

How much fresh water did Venice's cisterns supply? Assuming a baseline of eighty functioning, public cisterns in the fifteenth century, the economic historian Massimo Costantini calculated that, with an average volume of 230 cubic metres each, this would have meant a total capacity of 18,500 cubic metres. Water loss would have reduced this to an estimated 15,000 cubic metres (Costantini 1984, pp. 33-34). By the early $1500 \mathrm{~s}$ the number of public cisterns had risen to around 100, which would have provided some 20,000 cubic metres, alongside an estimated 2,700 private cisterns, providing an additional 180,000 cubic metres. For a population numbering in the region of 100,000 at the time, this would have meant a potential provision averaging 5.5 to $6 \mathrm{~L}$ per person per day. This is a reasonable amount by early modern standards (compared to Paris's 4 L: Sori 2001, p. 75), if somewhat low by modern baseline standards: World Health Organization guidelines suggest that $7.5 \mathrm{~L}$ a day per person is sufficient for hydration and incorporation into food, a figure which could be doubled to include basic hygiene needs (WHO 2018, p. 85; Klingborg and Finné 2018, p. 119). It accords with per capita availability estimates for rainwater cisterns on the island of Pantelleria, "a waterless land in the middle of the sea" (not unlike Venice) (Mantellini 2015, p. 408). And, like Venice, though on a much smaller scale, the numerous domestic cisterns provided enough capacity to sustain the local population. However, something like half of Venice's early modern population was probably dependent on public cisterns for their fresh water-with the other half benefiting from access to private cisterns - reducing average water provision for the poor to something like 1.4 L per person per day (Costantini 1984, pp. $45-46) .{ }^{33}$

Summer was an additional worry. As Sharp noted: "perhaps one of the greatest inconveniencies of these [Venetian] wells is that they do not contain water enough for a family in long droughts, which frequently happen in Italy" (Sharp 1767, p. 31). For this reason, the main "well" in the courtyard of the ducal palace, with its reliable water supply, "is so much frequented in the sommer time", according to Coryat, "that a man can hardly come thither at any time in the afternoon, if the sunne shineth very hote, but he shall finde some company drawing of water to drinke for the cooling of themselves" (Coryat 1905, I, p. 338). How did

\footnotetext{
33 In 1805 Pietro Lucchesi calculated that 30,000 of the city's 160,000 people were dependent on the 300 public and semi-public cisterns (1805, p. 36). Since in his estimation each public cistern could hold about 50 botti (42.3 cubic litres) of water, in extreme circumstances like siege, when it would not be possible to top them up with river water, a ration of one libbra $(0.94 \mathrm{~L})$ of water per person a day meant the 30,000 people being about to survive 150 days without any rain. Private cisterns tended to be smaller, as we have seen, holding 30 botti of water each, providing the remaining 130,000 people with a libbra of water per person a day for 130 days (ibid., p. 37).
} 
households manage their water use, since only the better-off could afford to purchase bargeloads of water for their cisterns?

Studies of domestic cistern use in other times and places provide a rough guide. The modelling undertaken by archaeologists Patrik Klingborg and Martin Finné of two ancient cisterns in Greece (2018), taking into account both the supply side - precipitation, roof area (catchment surface), water loss (through evaporation, leaking conduits or roof slope) - and the consumption side, suggests that the cisterns would have provided sufficient amounts of water to an average-size household. That said, volumes of water collected were highly variable, both from month to month and from year to year. Some of this variability was predictable: people knew that rainwater was collected primarily in winter and spring, providing a surplus necessary for the drier summer months, by the end of which the cisterns would often run dry (see also Mantellini 2015, p. 420). Nonetheless cistern management required "active participation" by members of the household to ensure that neither too much nor too little water was used at any given time (Klingborg and Finné 2018, p. 127). One had to avoid emptying the cistern early in the dry season and, at the other extreme, finding additional uses for water in order to prevent the cistern from overflowing during heavy rains. This was not only wasteful but was potentially damaging to both the surrounding area and the cistern structure itself and also risked allowing contaminants in. Perhaps for this reason, the two cisterns studied were intentionally built larger than the rooftop supply of rainwater; indeed, according to the authors' modelling, they were rarely full, reaching only half capacity during most months.

\section{Discussion: the ecologies of infrastructure in Venice, Naples and Rome}

In Venice fresh water for domestic uses was a limited good, on the one hand available gratis as a public utility and, on the other, as a commodity, to be had for a price. Four features characterise early modern Venice's unique cistern-system as explored in this study: (i) it utilised and developed existing technology to make the most of the city's unique natural and man-made environment; (ii) while stable in structure and function, it was able to expand in line with population growth, either by developing the water-capture technology or by constructing more cisterns; (iii) it provided adequate amounts of fresh water per person a day, by both early modern European and present-day baseline WHO standards; and, finally, (iv) it was managed from above by various overlapping authorities, with a more or less shared commitment by the general population.

By way of conclusion, let us examine this final point further. In the Introduction we asked what Venice's use and management of freshwater resources might tell us about the nature of power and society in the city. Was it top-down, bottom-up or shared out? Did the infrastructure build and sustain the political regime? Does the political nature of very different regimes mirror the cities' diverse water infrastructure? Let us briefly compare the politics of freshwater management in early modern Venice with that of two other significant early modern Italian cities, Naples and Rome, to explore what has been called the "ecologies of infrastructure" (Obertreis et al. 2016, p. 173). Not surprisingly, perhaps, the ways in which the water supply infrastructure was constructed and managed in these three cities varied according to differing "nature" and politics, ecological possibilities/constraints and forms of governance. 
In her study of the city's origins and development, Elisabeth Crouzet-Pavan's underlying theme is that Venice's struggle with its amphibious environment led to social concord, as manifested in its urban morphology and infrastructure (1992). To what extent is this true into the early modern period? By the time of the 1575-76 plague the city of Venice was part of an "aristocratic republic" (Zorzi 1990, p. 43). It was governed by a series of magistracies, offices and bureaucracies which were staffed by an elite class of patricians elected to shortterm office, in turn assisted by a small, privileged group of "citizens" (cittadini). The system was a functional one, characterised by an internal equilibrium (Burke 1992, pp. 107-109). That said, in recent decades historians have moved from viewing early modern Venice as the model of a stable, ordered and well-regulated society, to stressing its divisions, tensions, contradictions and flux (Martino and Romano 2000, pp. 7-9). The equilibrium Venice was famous for seems more the result of complex social relationships and interactions involving all levels of society, of which conflicts and tensions were an inherent part (Van Gelder and Judde de Larivière 2020, p. 7). Particularly if we are careful to distinguish between the rule and administration of the city of Venice itself (the focus of the present study) from that of the Terraferma, what emerges is how the organisation and management of water this was spread over a range of jurisdictions.

The way in which Venice's cistern-system both shaped and was shaped by socio-political forces is evident in the measures taken to keep the system operative on a day-to-day level. The relation between water, infrastructure and political rule in the city was "fluid", even if the cistern-system itself was remarkably stable over time, not unlike the State of which it was a part. That said, when it came to freshwater management, Venice may have been a republic, but power flowed in a different way to that of the Dutch republic, with its "water boards". These emerged from the twelfth century onwards, with judiciary and regulatory powers to maintain dykes, drainage canals and other water management works. Their parcellation into numerous separate jurisdictions constituted "polycentric governance" (Mostert 2012) and they are considered as the Dutch republic's oldest democratic institutions (Mostert 2020, pp. 320-321). In Venice by contrast, policies were determined from above by the three magistracies with jurisdiction over the cistern-system, and imposed paternalistically on the various actors who made the system function, such as the watermen. Of course, given the nature of the city's morphology, all inhabitants had a vested interest in keeping its paved surfaces clean and free of rubbish, since they were the source of drinking water. Not all was sweetness and light, however. If we consider the "everyday politics" of infrastructures (Meadowcroft 2009), we see how their use might be contested: how people continued to throw rubbish into the streets and canals, trades made illicit use of freshwater resources and watermen protested at the high tolls they were forced to pay. The "quiet" city of Venice had its moments of popular resistance and contestation (van Gelder 2018, p. 291). The multiplicity of layers of authority and control and of different, overlapping jurisdictions when it came to managing cistern maintenance, freshwater use and the cleanliness of the city was typical of the way power was distributed. Overlapping jurisdictions could be messy and contested but they had the advantage of ensuring the participation of different interest groups. Although ultimately hierarchical, rather than being concentrated authority was spread out, with frequent recourse to "expertise" from outside, including the likes of Annibale Raimondo.

How do the ecologies of infrastructure in Naples and Rome compare? In some ways, Naples is most similar to Venice, despite its very different hydrological and political 
regimes. In Naples, an ancient water infrastructure was adapted to early modern needs. Known collectively as the "Formale Reale" (royal reservoir), two aqueducts, one ancient and the other dating from the early seventeenth century, brought water to a series of vast underground basins, excavated out of the rock on which the city was built. These were linked by a complex series of channels and secondary branches. The underground reservoirs were accessed by means of pozzi (well-shafts), bronzi (bronze spouts) and conduits which brought water to palaces, religious institutions and workplaces. Although it was possible to augment the number of concessions accessing the reservoirs to meet the needs of the city's increasing population, the overall water supply remained constant; moreover newer areas of Naples were not served by the system and had to make due with groundwater wells. In my study of the management of water supply of the city, then under Spanish rule, I suggested that its everyday management provided evidence of the "collision and collusion" between the different layers of government in the exercise of authority (Gentilcore 2019). This descended from the Spanish monarch's representative in Naples, the viceroy; through to the local noble and urban elites serving as deputies for the "Tribunale della Fortificazione, Acqua e Mattonata", a sort of public works department; all the way down to the pozzari (well-attendants) labouring at the coalface. An established hierarchy of official roles and functions was perforce dispersed across a multiplicity of agents and sources of expertise and practical knowledge. Power was shared out and negotiated.

Early modern Rome was rather different. Here, water politics were more clearly hierarchical, during a time when the city went from relying on the River Tiber for its supply to a renewed and monumental aqueduct system. The fountains for which the city would become famous were made possible by the restoration and/or construction of three aqueducts: the Acqua Vergine (1560-70), the Acqua Felice (1585-87) and the Acqua Paola (1607-12). These projects, sponsored by successive popes, formed part of a broader strategy to restore the prestige of the Catholic Church through the physical restoration of the Rome itself. By 1630 , the city was more abundantly served by water than any other in Europe. Rome's renewed water flowed by means of "the strict social gravity of paternalism" (Rinne 2010, p. 188): originating with a reigning pope, who controlled the taps, the water flowed down first to the cardinals, the Roman Council or noble families, monasteries and churches, and then to the public. As an example of this, the papal "Congregatio super viis, pontibus et fontibus" (cardinals' Committee in Charge of Roads, Bridges and Fountains) was established with precedence over the pre-existing "Maestri delle Strade" (Masters of the Streets: a civic, secular bureaucracy with responsibility for Rome's roads, bridges and fountains), as part of the papacy's ongoing struggle to erode civil authority (ibid., 52-53). Moreover, water access, in the form of a subscription, was a form of patronage: given or sold by the pontiff, or by the cardinals on the "Water Committee", to repay financial and social debts, strengthen familial and institutional alliances, honour services rendered and curry favour (ibid., p. 77).

Likewise, Rome's public fountains - variously, for drinking and cooking uses, for animals, for laundry, for trades - were gifted. When the city's Jewish ghetto received its own public fountain in 1614, it came in the form of a gift from Pope Paul V (ibid., pp. 153-154). This may have been an improvement over the situation facing the Jews of Venice who, as we have seen, had to rent access to their fountains; but it does emphasise the top-down nature of water provision and organisation in early modern Rome. Then again, Venice's numerous public cisterns were also gifted by the authorities, their well-heads proudly sculpted with the lion of St Mark, lest Venetians forget. This reminds us that, despite the substantially 
different ways in which fresh water was accessed, distributed and managed in each of the three urban environments, there were clearly similarities between them. All were part of the hierarchically ordered but politically fragmented societies typical of early modern Europe.

Acknowledgements A short draft of this study was presented at the online workshop "Natural resources in early modern economies of knowledge", organised by Helge Wendt and Pietro Daniel Omodeo (Max Planck Institute for the History of Science, Berlin, April 2021). I am also very grateful to my Venetian colleagues Diego Calaon, Giorgio Gianighian and Craig Martin, as well as to the two anonymous reviewers of this journal, for their insights and suggestions; of course, any errors remain my own. The Italian translations are mine unless indicated otherwise.

Funding This article is part of the "Water cultures of Italy, 1500-1900" Advanced Grant, PI David Gentilcore, funded by the European Research Council under the European Union's Horizon 2020 research and innovation programme, grant agreement no. 833834 .

\section{Open access funding provided by Università Ca' Foscari Venezia within the CRUI-CARE Agreement.}

Open Access This article is licensed under a Creative Commons Attribution 4.0 International License, which permits use, sharing, adaptation, distribution and reproduction in any medium or format, as long as you give appropriate credit to the original author(s) and the source, provide a link to the Creative Commons licence, and indicate if changes were made. The images or other third party material in this article are included in the article's Creative Commons licence, unless indicated otherwise in a credit line to the material. If material is not included in the article's Creative Commons licence and your intended use is not permitted by statutory regulation or exceeds the permitted use, you will need to obtain permission directly from the copyright holder. To view a copy of this licence, visit http://creativecommons.org/licenses/by/4.0/.

\section{References}

Bamji A (2007) The control of space: dealing with diversity in early modern Venice. Italian Studies 62(2):175-188

Bamji A (2020) Blowing smoke up your arse: drowning, resuscitation, and public health in eighteenth-century Venice. Bull Hist Med 94(1):29-63

Barker H (2014) Egyptian and Italian merchants in the Black Sea slave trade, 1260-1500. Dissertation, Columbia University

Benedetti R (1577) Nuovi avvisi di Venetia, ne' quali si contengono tutti i miserabili che in quella al tempo della peste sono occorsi. Battista de' Bartoli, Urbino

Bevilacqua P (1998) Venezia e le acque. Donzelli, Rome

Bichsel C (2016) Water and the (infra-)structure of political rule: a synthesis. Water Alternatives 9(2):356-372

Boito C, ([1876] (1990) Il colore a Venezia. In: Il maestro di setticlavio (novelle veneziane). Passigli, Florence

Bortoletto M (2008) Evidenze archeologiche di strutture per la lavorazione delle stoffe nella Venezia bassomedievale. Archeologia Veneta 31:237-249

Bortoletto M (2011) Venezia: sistemi costruttivi delle “cisterne alla veneziana” dal tardo medioevo all'epoca moderna. In: Cipriano S, Pettenò E (eds) Archeologia e tecnica dei pozzi per acqua dalla pre-protostoria all'età moderna. Editreg, Trieste, pp 193-203

Burke P (1992) History and social theory. Polity, Cambridge

Calabi D, Camerino U, Concina E (1996) La città degli ebrei. Marsilio, Venice

Casellato A (2014) Venezia dei bassifondi: la città dei marginali, della classe operaia e del pittoresco popolare. Laboratoire italien, http://journals.openedition.org/laboratoireitalien/828 (accessed 2/2/2021)

Cecchini I (2020) Patterns of consumption in Renaissance Venice. Studi di storia 13:476-493

Chojnacka M (2001) Working women of early modern Venice. Johns Hopkins University Press, Baltimore

Ciriacono S (2006) Building on water: Venice, Holland and the construction of the European landscape in early modern times. Berghahn, New York

Ciriacono S (2018) Management of the lagoon and urban environment in 18th-century Venice. Water History 10:141-161

Cohn SK (2007) The Black Death and the burning of the Jews. Past Present 196:3-36 
Cohn SK (2010) Cultures of plague: medical thinking at the end of the Renaissance. Oxford University Press, Oxford

Coryat T (1905) Coryat's crudities, hastily gobbled up in five months travels in France, Savoy, Italy [1611]. James MacLehose and Sons, Glasgow

Costantini M (1984) L'acqua di Venezia. L'approvvigionamento idrico della Serenissima. Arsenale Editore, Venice

Crouzet-Pavan E (1992) "Sopra le acque salse": espaces, pouvoir et société à Venise à la fin du moyen âge. Ecole Française de Rome, Rome, 2 vols

Cusumano N (2007) Ebrei e accuse di omicidio ritual: in margine a un libro di Ariel Toaff. Mediterranea: Richerche Storiche 4:141-152

De Beer ES (ed) (1959) The Diary of John Evelyn. Oxford University Press, London

Dell'Aquila F, Foschino F, Paolicelli R (2020) Nuove acquisizioni sull'approvvigionamento idrico nel Materano in epoca medievale. In: De Minicis E, Pastura G (eds) Il rupestre e l'acqua nel Medioevo: religiosità, quotidianità, produttività. All'Insegna del Giglio, Florence, 123-132

Figuier L (1875) Les merveilles de l'industrie ou description des principals industries modernes. Furne, Jouvet et C.ie, Paris

Filiasi G (1796-97) Memorie storiche de' Veneti primi e secondi. 7 vols. Modesto Fenzo, Venice

Franck L (1999) Eau à tous les étages: l'aventure de l'eau à domicile à travers l'histoire de la Compagnie Générale des Eaux. Vivendi SA, Paris

Gallina G (1924) Le serve al pozzo: commedia in quattro atti. Treves, Milan

Gentilcore D (2019) “Cool and tasty waters”: managing Naples's water supply, c. 1500-c. 1750. Water History $11: 125-151$

Gentilcore D (2020) From "vilest beverage" to "universal medicine": drinking water in printed regimens and health guides. Soc Hist Med 33(3):1450-1750 683-703

Gianighian G (1982) La casa veneziana complessa del Rinascimento: un'invenzione contro il consumo di territorio. In: (no ed) D'une ville à l'autre: structures matérielles et organisation de l'espace dans le villes européennes (XII-XVI siècle). Ecole Française de Rome, Rome, pp 557-590

Gianighian G (1983) Scarichi veneziani in epoca moderna: canoni da acqua e canoni da necessario. Studi Veneziani 7:161-182

Gianighian G (2004) Building a Renaissance double house in Venice. Architectural Research Quarterly $8(3-4): 299-312$

Gianighian G (2005) Building Castelforte. Architectural Research Quarterly 9(1):51-68

Giormani V (2010) Acqua potabile per Venezia. Studi Veneziani 60:325-374

Goethe JW (1970) Italian journey (1786-1788). Trans. W H Auden and E Mayer. Penguin Books, Harmondsworth

Goldoni C (1738) L'uomo di mondo: commedia in tre atti. https://www.liberliber.it/mediateca/libri/g/ goldoni/1_uomo_di_mondo/pdf/1_uomo_p.pdf (accessed 2/2/2021)

Grano MC (2020) Palombari, cisterne e pozzi per l'approvvigionamento idrico nei Sassi di Matera (Basilicata). Il Capitale Culturale 21:377-389

Grevembroch G (1981) Gli abiti de veneziani di quasi ogni età con diligenza raccolti e dipinti nel secolo XVIII. Filippi, Venice. 4 vols

Guainerio T (1577) Il trattato delle fontane et acque di Ritorbo. Lyon, Jacobo Gionti

Guerzoni S, Tagliapietra D (2006) Atlante della laguna: Venezia tra terra e mare. Marsilio, Venice

Henderson J (2010) Public health, pollution and the problem of waste disposal in early modern Tuscany. In: Cavaciocchi S (ed) Le interazioni fra economia e ambiente biologico nell'Europa preindustriale secc. XIII-XVIII / Economic and biological interactions in pre-industrial Europe from the 13th to the 18th centuries. Firenze University Press, Florence, pp 373-382

Howells W ([1866] 1883) Venetian life. Bernhard Tauchnitz, Leipzig

Ioly Zorattini PC (1968) Fervore di educazione ebraica nelle Comunità venete del ‘700. La Rassegna Mensile di Israel 34(10):582-591

Jørgensen D (2010a) All good rule of the cite": sanitation and civic government in England, 1400-1600. Journal of Urban History 36(3):300-315

Jørgensen D (2010b) “The Metamorphosis of Ajax”, jakes, and early modern urban sanitation. Early English Studies $3: 1-31$

Judde de Larivière (2020) Political participation and ordinary politicization in Renaissance Venice: was the popolo a political actor? In: Van Gelder M, Judde de Larivière C (eds) Popular politics in an aristocratic republic: political conflict and social contestation in late medieval and early modern Venice. Routledge, London, pp 69-87

Klingborg P, Finné M (2018) Modelling the freshwater supply of cisterns in ancient Greece. Water History 10:113-131

Laureano P (1993) Giardini di pietra. I Sassi di Matera e la civiltà mediterranea. Bollati Boringhieri, Turin 
Lemire V (2001/2) Les puits du Ghetto: conflits de mémoire et logiques d'appropriation (Venise, 14501650). Histoire urbaine 4(2): 105-125

Lilli E (2008) Le lavandaie nella Roma del Settecento. Genesis 7(1-2):193-217

Loen S (2020) Thirsty cities: learning from Dutch water supply heritage. In: Hein C (ed) Adaptive strategies for water heritage. Springer, Cham, pp 78-103

Long P (2018) Engineering the Eternal City: infrastructure, topography, and the culture of knowledge in late sixteenth-century Rome. University of Chicago Press, Chicago

Lucchesi P (1805) Memorie sopra le cisterne o pozzi di Venezia. Francesco Andreola, Venice

Magnusson R (2001) Water technology in the Middle Ages: cities, monasteries and waterworks after the Roman Empire. Johns Hopkins University Press, Baltimore

Mantellini S (2015) The implications of water storage for human settlement in Mediterranean waterless islands: the example of Pantelleria. Environmental Archaeology 20(4):406-424

Marangoni G (1974) Le associazioni di mestiere nella Repubblica Veneta. Filippi, Venice

Marini A (1923) Discorso sopra l'aere di Venezia [1559]. In: Segarizzi A (ed) Antichi scrittori d'idraulica veneta, vol 4. C. Ferrari, Venice

Martin J, Romano D (eds) (2000) Venice reconsidered: the history and civilization of an Italian city-state. Johns Hopkins University Press, Baltimore. Editors' introduction, pp. 1-35, pp 1297-1797

Mays L, Antoniou G, Angelakis A (2013) History of water cisterns: legacies and lessons. Water 5:1916-1940

Meadowcroft J (2009) What about the politics? Sustainable development, transition management, and long term energy transitions. Policy Sci 42(4):323-340

Migliorini B (1936) I nomi italiani del tipo “bracciante". Vox Romanica 1:64-85

Misson FM (1695) A new voyage to Italy. R. Bently, London [Eng. trans. of Nouveau voyage d'Italie, 1691]

Molà L (2010) La Repubblica di Venezia tra acque dolci e acque salse: investimenti tecnologici a Lizzafusina nel Rinascimento. In: Calzona A and Lamberini D (eds) La civiltà delle acque tra Medioevo e Rinascimento. Olschki, Florence, vol. 2, pp. 447-472

Montaigne M de (1903) The journal of Montaigne's travels in Italy by way of Switzerland and Germany in 1580 and 1581. Trans. W. G. Waters. John Murray, London, 3 vols

Moryson F, ([1617] (1907) An itinerary: containing his ten years travel through the Twelve Dominions of Germany, Bohemia, Switzerland, Netherland, Denmark, Poland, Italy, Turkey, France, England, Scotland and Ireland. James MacLehose and Sons, Glasgow

Mostert E (2012) Water management on the island of IJsselmonde 1000 to 1953: polycentric governance, adaptation, and petrification. Ecol Soc 17(3):12. http://www.ecologyandsociety.org/vol17/iss3/art12/ (accessed 2/2/2021)

Mostert E (2020) Water and national identity in the Netherlands: the history of an idea. Water History 12:311-329

Naphy W (2002) Plagues, poisons and potions: plague-spreading conspiracies in the Western Alps c. Manchester University Press, Manchester, pp 1530-1640

Obertreis J, Moss T, Mollinga P, Bichsel C (2016) Water, infrastructure and political rule: Introduction to the Special Issue. Water Alternatives 9(2):168-181

Ongania F (1911) Raccolta delle vere da pozzo in Venezia. Tipografia Emiliana, Venice

Palmer RJ (1978) The control of plague in Venice and Northern Italy 1348-1600. Dissertation, University of Kent at Canterbury

Palumbo Fossati Casa I (2013) Dentro le case: abitare a Venezia nel Cinquecento. Gambier \& Keller, Venice

Passarella C (2017) La pena di morte a Venezia in età moderna. Historia et Ius, 11, paper 14 http://www. historiaetius.eu/uploads/5/9/4/8/5948821/passarella_11.pdf (accessed 2/2/2021)

Pastore A (2007) Dal lessico della peste: untori, unzioni, unti. Acta Histriae 15(1):127-138

Plebani T (2016) Lo spazio urbano del Settecento a Venezia e l'agency delle donne. In: Berger C, Coletti F (eds) Les figures du féminin "en rupture" à Venise: courtisanes, actrices, épouses, servants et "putte" (XVIe-XVIIIe siècles). Université Toulouse II-Jean Jaurès, Toulouse, pp 125-143

Ponti C (1870) Catalogo generale delle fotografie pubblicate da Carlo Ponti. Tipografia Ripamonti-Ottolini, Venice

Porzio LA (1747) The soldier's vade mecum or the method of curing the diseases and preserving the health of soldiers. Dodsley R, London (Eng. Trans. of: De militis in castris sanitate tuenda, Vienna 1685)

Preto $\mathrm{P}$ (1978) Peste e società a Venezia nel 1576. Neri Pozza, Vicenza

Price DH (1994) Wittfogel's neglected hydraulic/hydroagricultural distinction. J Anthropol Res 50(2):187-204

Pullan B (1964) Wage-earners and the Venetian economy. Econ Hist Rev 16(3):1550-1630 407-426

Quillien R, Rivoal S (2020) Boatmen, fishermen and Venetian institutions: from negotiation to confrontation. In: Van Gelder M, Judde de Larivière C (eds) Popular politics in an aristocratic republic: political conflict and social contestation in late medieval and early modern Venice. Routledge, London, pp 197-216 
Raimondo A (1576) Discorso nel quale chiaramente si conosce la viva et vera cagione che ha generato le fiere infermità che tanto hanno molestato l'anno 1575 et tanto il ' 76 acerbamente molestano il popolo de l'invittissima città di Venetia. S.n., Padua

Rangoni T (1577) Come il serenissimo doge di Vinegia, il S. Sebastian Veniero e li Venetiani possano viver sempre sani. Marco Bindoni, Venice

Rinne KW (2001/2) The landscape of laundry in late Cinquecento Rome. Studies in the Decorative Arts 9(1): 34-60

Rinne KW (2010) The waters of Rome: aqueducts, fountains, and the birth of the baroque city. Yale University Press, New Haven

Roche D (1984) Le temps de l'eau rare du Moyen Âge à l'époque moderne. Annales Économies Sociétés Civilisations 39(2):383-399

Roncaglia E (2009) Carlo Naya fotografo veneziano: il ruolo della fotografia del XIX secolo nella rappresentazione del paesaggio urbano. Dissertation, University of Padua

Romano D (1996) Housecraft and statecraft: domestic service in Renaissance Venice. Johns Hopkins University Press, Baltimore

Sagredo A (1856) Statistica delle arti, 1773. In: Sulle consorterie delle arti edificative in Venezia. P. Naratovich, Venice, pp 232-278

Sansa R (2002) L'odore del contagio: ambiente urbano e prevenzione delle epidemie nella prima età moderna. Medicina e Storia 3(2002): 83-108

Sansa R (2006) Le norme decorose e il lavoro sporco: l'igiene urbana in tre capitali europee, Londra, Parigi, Roma tra XVI e XVIII secolo. Storia urbana 29(3):85-112

Sansovino F (1581) Venetia città nobilissima et singolare descritta in XIIII libri. Iacomo Sansovino, Venice

Sanudo M (1980) De origine, situ et magistratibus urbis Venetae, ovvero la città di Venetia (1493-1530). Caracciolo Aricò A (ed) Cisalpino-La Goliardica, Milan

Savonarola M (1515) Libreto ... de tutte le cose che se manzano comunamente. Bernardino Benalio, Venice

Savonarola M (1902) Libellus de ornamentis Padue. In: Muratori LA (ed) Raccolta degli storici italiani, vol. 24 part 15. S. Lapi, Città di Castello

Sharp S (1767) Letters from Italy, describing the customs and manners of that country in the years 1765 and 1766. Henry and Cave, London

Skelton L (2016) Sanitation in urban Britain, 1560-1700. Routledge, London

Sori E (2001) La città e i rifiuti: ecologia urbana dal Medioevo al primo Novecento. Il Mulino, Bologna

Tassini G (1882) Curiosità veneziane ovvero origini delle denominazioni stradali di Venezia. M. Fontana, Venice

Tentori C (1792) Delle legislazione veneziana sulle preservazione della laguna: dissertazione storico-filosofico-critica. Giuseppe Rosa, Venice

Tilt B (2015) Dams and development in China: the moral economy of water and power. Columbia University Press, New York

Tsakiri R (2018) Cisterne, pozzi, fontane ed altre opere idrauliche: l'acqua come potenza movente per le città di dominio veneto. Creta ed Isole Ionie (secoli XVI-XVIII). In: [no ed.] Gestione dell'acqua in Europa (XII-XVIII secc.) / Water management in Europe (12th-18th centuries). Firenze University Press, Florence, pp 279-304

Tüskés A (2010) Venetian well-heads in nineteenth-century taste. Sculpture Journal 19(1):49-61

Ulvioni P (1989) Il gran castigo di Dio: carestia ed epidemie a Venezia e nella Terraferma. Franco Angeli, Milan, pp 1628-1632

Van Gelder M (2018) The people's prince: popular politics in early modern Venice. Journal of Modern History $90: 249-291$

Van Gelder M, Judde de Larivière (2020) Introduction. In: Van Gelder M, Judde de Larivière C (eds) Popular politics in an aristocratic republic: political conflict and social contestation in late medieval and early modern Venice. Routledge, London: pp 1-21

Vanzan Marchini NE (1979) Medici ebrei e assistenza cristiana nella Venezia del '500. La Rassegna Mensile di Israel 45(4/5):132-161

Vanzan Marchini NE (1995) Le leggi di sanità della Repubblica di Venezia. Vicenza, Neri Pozzi, 5 vols. [Reproduces: ASVe, Provveditori alla Sanità, Boncio GA, Rubrica delle leggi ecc. del Magistrato eccellentissimo alla Sanità, 1793, bb. 7-11]

Vanzan Marchini NE (2009) Venezia civiltà anfibia. Cierre, Sommacampagna

Vazzoler M (1999) La diffusione degli inquinanti nei canali interni di Venezia. In: Caniato G, Carrera F, Giannotti V, Pypaert P (eds) Venezia, la città dei rii. Cierre, Verona, pp 55-60

Veneziani S (2016) Il ruolo delle condizioni igienico-sanitarie a Bari nella politica di costruzione dell'Acquedotto Pugliese. Acta Medico-Historica Adriatrica 14(2):229-248 
Vianello A (1999) Casa e bottega: I lavoratori "poveri” e le loro famiglie attraverso gli archivi delle fraterne parrocchiali nella Venezia del Settecento. In: Guenzi A, Massa P, Moioli A (eds) Corporazioni e gruppi professionali nell'Italia moderna. Franco Angeli, Milan, pp 755-778

Wheeler Jo (2007) Stench in sixteenth-century Venice. In: Cowan A, Steward J (eds) The city and the senses: urban culture since 1500. Aldershot, Ashgate, pp 25-38

WHO (World Health Organization) (2018) Guidelines for drinking-water quality: fourth edition incorporating the first addendum. https://www.who.int/publications/i/item/9789241549950 (accessed 2/2/2021)

Wijntjes WC (1982) The water supply of the medieval town. In: Rotterdam Papers 4: A contribution to medieval archaeology 4: 189-203

Wittfogel K (1957) Oriental despotism: a comparative study if total power. Yale University Press, New Haven Wolff L (2012) Paolina's innocence: child abuse in Casanova's Venice. Stanford University Press, Stanford

Zaggia S (2004) "Far la città". Il ruolo dei Provveditori di Comun nell'evoluzione dell'ambiente urbano di Venezia: strade, ponti, pozzi, case. Mélanges de l'École française de Rome. Italie et Méditerranée 116(2):665-681

Zompini G (1785) Le arte che vanno per via nella città di Venezia. S.n., Venice

Zonca V (1607) Novo teatro di machine et edificii per varie et sicure operationi. Pietro Bertelli, Padua

Zorzi A (1990) La vita quotidiana a Venezia nel secolo di Tiziano. Rizzoli, Milan

Zorzi F di (1596) Dell'aria et sue qualità: discorso. Gio. Anto. Rampazetto, Venice

Publisher's Note Springer Nature remains neutral with regard to jurisdictional claims in published maps and institutional affiliations. 
David Gentilcore is full professor of early modern history at Ca' Foscari University Venice and PI for the European Research Council Advanced Grant "The water cultures of Italy, 1500-1900". He is interested in the social and cultural history of Italy, in its European and Mediterranean context, in particular with regard to issues relating to the management of health and diet, the circulation of knowledge, and power and authority. His most recent book is Food and health in early modern Europe (London 2016). 